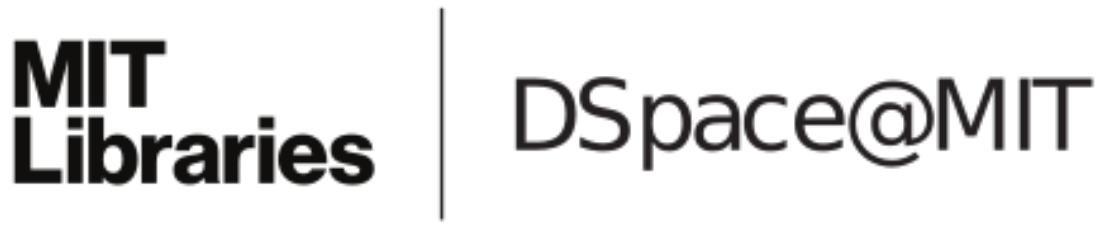

\author{
MIT Open Access Articles
}

The Effect of Tax Authority Monitoring and
Enforcement on Financial Reporting Quality

The MIT Faculty has made this article openly available. Please share how this access benefits you. Your story matters.

Citation: Hanlon, Michelle, Jeffrey L. Hoopes, and Nemit Shroff. "The Effect of Tax Authority Monitoring and Enforcement on Financial Reporting Quality." The Journal of the American Taxation Association 36, no. 2 (November 2014): 137-70.

As Published: http://dx.doi.org/10.2308/atax-50820

Publisher: American Accounting Association

Persistent URL: http://hdl.handle.net/1721.1/98870

Version: Author's final manuscript: final author's manuscript post peer review, without publisher's formatting or copy editing

Terms of use: Creative Commons Attribution-Noncommercial-Share Alike 


\title{
The Effect of Tax Authority Monitoring and Enforcement on Financial Reporting Quality
}

\author{
Michelle Hanlon \\ mhanlon@mit.edu \\ Massachusetts Institute of Technology \\ Jeffrey L. Hoopes \\ hoopes@fisher.osu.edu \\ Ohio State University \\ Nemit Shroff \\ shroff@mit.edu \\ Massachusetts Institute of Technology
}

\section{Forthcoming at the Journal of the American Taxation Association}

\begin{abstract}
This paper examines the relation between tax enforcement and financial reporting quality. The government, due to its tax claim on firm profits, is de facto the largest minority shareholder in almost all corporations. Therefore, the government, like other shareholders, has an interest in the accurate reporting of (taxable) income and preventing insiders from siphoning corporate funds to obtain private benefits. We hypothesize and find evidence that higher tax enforcement by the tax authority has a positive association with financial reporting quality. Further, we find that this association is generally stronger when other monitoring mechanisms are weaker. Our evidence is consistent with the predictions from the Desai, Dyck, and Zingales (2007) theory that the tax authority provides a monitoring mechanism of corporate insiders. Our paper also adds to the literature on the determinants of financial reporting quality and how the relation between accounting standards and reporting outcomes depends on country level institutions.
\end{abstract}

Key Words: Tax Enforcement; Financial Reporting Quality; Earning Quality; IRS Audit JEL Classification: G3; H25; H26; K34; M40

We appreciate helpful comments from John Phillips (editor), two anonymous reviewers, Scott Dyreng, Shane Heitzman, Daniel Saavedra, Terry Shevlin, D. Shores, Jake Thornock, Luo Zuo, and workshop participants at Texas A\&M University, the University of Michigan, the University of Michigan Public Finance Group, and the University of Washington. We thank the Harry Jones Endowment for Earnings Quality Research at the University of Michigan for financial support. We thank Susan Long of the Transactional Records Access Clearinghouse and Ruth Schwartz of the Statistical Information Service of the Internal Revenue Service for providing us with detailed information about the IRS. Nemit Shroff and Jeffrey Hoopes acknowledge financial support from the Deloitte Foundation and the Paton Fellowship at the University of Michigan. All errors are our own. 
A hand from Washington will be stretched out and placed upon every man's business; the eye of the Federal inspector will be in every man's counting house...

Richard Byrd, Speaker of the Virginia House of Delegates, 1913, in a speech opposing the 16th Constitutional Amendment.

\section{Introduction}

Most large corporations are characterized by a separation of ownership and control, which provides opportunities for managers to act in their self-interest and divert resources for private benefit at the expense of shareholders (Jensen and Meckling 1976). Individual shareholders, who own only a fraction of the company, have limited incentives to spend personal resources to monitor managers because they derive only a small fraction of these monitoring benefits. One oft-neglected but potentially large stakeholder that is common to all companies is the government (Dyck and Zingales 2004). Specifically, due to its tax claim on a firm's profits, the federal government is de facto the largest minority shareholder in almost all corporations. Thus, the government (via the taxing authority) has an interest in determining the 'true' profit earned by companies and getting its share of profits. Further, unlike most minority shareholders, the government does not face free-rider problems in monitoring managers and preventing them from diverting resources for private benefit. As a result, the tax authority is likely to monitor managers in an effort to reduce wealth diversion, and an increase in tax authority monitoring and enforcement (hereafter, enforcement for ease of exposition) is likely to discourage wealth diversion by managers (Desai, Dyck, and Zingales 2007).

In this paper, we examine whether tax enforcement by the tax authority affects the quality of financial reporting. Our motivation for examining the relation between tax enforcement and financial reporting quality follows from recent research by Dyck and Zingales (2004), Desai, Dyck, and Zingales (2007), and Desai and Dharmapala (2009). The general thesis is that when managers engage in tax avoidance they must conceal such actions from the tax authority. Thus, managers must obfuscate their transactions and this obfuscation may permeate all reporting 
venues, including tax reporting and financial reporting. Once manager actions are hidden via this obfuscation, they then have some latitude to extract wealth and divert rents from shareholders. Our prediction is that if tax authority enforcement reduces tax avoidance, then tax authority enforcement is likely to have a positive spillover effect on financial reporting quality through the reduced obfuscation resulting from reduced tax avoidance. It is important to recognize that tax authorities are not interested in improving financial reporting quality per se. The effect on financial reporting quality is a byproduct of the tax authorities' interest in the accurate reporting of taxable income. Our hypothesis is that the enforcement of the tax code leads to a reduction in managerial obfuscation and diversion, and thus improves financial reporting quality.

We define 'financial reporting quality' as the precision or accuracy with which financial statements capture the performance of a company, and 'managerial diversion' encompasses any action benefiting managers that is not in the interest of shareholders or the government. For example, the manipulation of earnings in a manner that increases current and future compensation to managers is a form of diversion. Since managerial compensation is often tied to financial accounting earnings both directly (via earnings based bonuses) and indirectly (via the stock price), any attempts to increase or decrease earnings (for smoothing purposes) can be interpreted as diversion at the expense of other stakeholders.

Ex ante, it is unclear whether tax authority enforcement affects financial reporting quality. First, most observers contend that the tax authority (the IRS in the case of the U.S.) is outgunned by corporations in terms of both talent and financial resources (e.g., Novack and Saunders 1998). Second, in the U.S., the government has other agencies and regulations specifically established to monitor financial reporting (the SEC). Thus, whether the tax authority can or does affect financial reporting quality is a debatable and open question. 
We proxy for tax authority enforcement with the ex post likelihood of an IRS audit (Guedhami and Pittman 2008). ${ }^{1}$ The data we use to measure the likelihood of a face-to-face audit are from the Transactional Records Access Clearinghouse (TRAC) at Syracuse University. Using TRAC data has the following advantages. First, TRAC obtains data on actual audit rates directly from the IRS from the same system that the IRS uses to generate reports for Congress, the public, and for internal use. Therefore, the data are likely to be reliable. Hoopes, Mescall, and Pittman (2012) at least partially validate the TRAC data by showing that IRS audits rates from TRAC are negatively associated with tax avoidance. Second, the data apply to U.S. companies thus allowing tests of the effects of enforcement using data from one country. Using data from one country eliminates the common concerns of drawing inferences based on cross-country data such as the effects of different institutional factors and different accounting standards on reporting quality. Third, the IRS aggregates audit rates by eight firm size groups each year which are then used to compute audit probabilities. The method of aggregation reduces concerns that managers can affect the probability of an IRS audit (e.g., by changing the book-tax difference), mitigating concerns of reverse causality (Guedhami and Pittman 2008; El Ghoul et al. 2011).

We measure financial reporting quality using two proxies. First, we measure reporting quality as the extent to which accruals map into past, current, and future cash flows (Dechow and Dichev 2002; McNichols 2002). Second, we measure reporting quality as the absolute value of discretionary accruals (Jones 1991; Dechow, Sloan, and Sweeney 1995). We select our measures of reporting quality with the objective of uncovering the link between tax authority oversight and the error in representing the firm's fundamental earnings process. Our empirical measures are hence designed to be sensitive to both intentional and unintentional misrepresentation of the earnings process. We discuss this in greater detail in Section 3.

\footnotetext{
${ }^{1}$ Since we proxy for the ex ante threat of an IRS audit using ex post IRS audit rates, our specification assumes that managers form rational expectations about the audit rates. In sensitivity tests, we relax this assumption by measuring IRS audit probability using lagged audit rates.
} 
We find that IRS audit probability is positively associated with accrual quality (i.e., a higher audit probability leads to a better mapping of accruals to cash flows) and that IRS audit probability is negatively associated with discretionary accruals (unsigned). These results collectively suggest that tax authority enforcement is positively associated with financial reporting quality. Our inferences are robust to controlling for observable firm level characteristics and unobservable time invariant firm characteristics with firm fixed effects. The inclusion of firm fixed effect restricts variation in financial reporting quality to that within the firm, thereby reducing the likelihood of an omitted variables bias.

Next, we examine whether tax authority enforcement has a more prominent association with financial reporting quality when other external monitors are weak. That is, if external monitors (e.g., institutional investors) are successful in preventing managers from diverting wealth away from shareholders and thus improving financial reporting quality, then additional monitoring from the tax authority via greater enforcement is likely to have a weaker incremental effect on reporting quality. Consistent with our prediction, we find that the association between tax authority enforcement and financial reporting quality is weaker when the proportion of the firm owned by institutional investors and dedicated institutional investors is high (Bushee 1998). Overall, these findings are consistent with the theory proposed by Desai et al. (2007) that tax enforcement is negatively associated with managerial diversion.

An important concern with our research is that our primary proxy for tax authority enforcement only varies with firm size and time, albeit in a non-linear fashion. Hence, if financial reporting quality varies for some other reason across the same size and time periods as tax enforcement, then it is conceivable that we are incorrectly attributing time and size effects to tax enforcement. To address the concern about size and time effects, we verify the robustness of our results using a plethora of tests. First, we explicitly control for size and time period effects on financial reporting quality. Second, we use an alternative proxy that incorporates geographic variation in tax enforcement within the U.S. (which is available for the shorter time period 1992 
to 2000). In addition, we employ seven additional measures of IRS enforcement from the TRAC data - (i) the number of IRS criminal investigation referrals, (ii) the number of corporate tax prosecutions, (iii) the number of corporate civil penalties due to fraud and (iv) due to negligence, (v) the number of IRS permanent employees, (vi) the number of IRS revenue agents, and (vii) the number of IRS criminal investigators. Our results are robust to each of these measures which are far less reliant on variation in firm size. Finally, we use bootstrap methods to randomly assign firms to different IRS audit size pools within each year and re-estimate our regressions. In all of the tests described above, we find that tax enforcement positively affects reporting quality.

We then conduct two additional tests using completely different data that do not have the same limitations as the TRAC data. First, we return to the setting identified by Desai et al. (2007) to test our hypotheses. Specifically, we use the tax enforcement crackdown executed by Vladimir Putin in Russia as a setting to test whether the change in tax enforcement led to an improvement in earnings informativeness. We use earnings informativeness as a proxy for financial reporting quality rather than accruals quality and discretionary accruals because data availability in Russia limits our use of these other measures. We find that the informativeness of earnings of Russian firms improved following the tax enforcement efforts implemented by Vladimir Putin. We also find that the increase in earnings informativeness is lower for Russian firms cross-listed in the U.S. - i.e., firms perceived to have stronger corporate governance practices and other monitoring mechanisms in place (Coffee 1999; Stulz 1999; Hail and Leuz 2009). These findings reinforce the arguments that tax enforcement is associated with financial reporting quality and that the relation between tax enforcement and reporting quality is stronger when there are fewer other monitors.

Second, we find that annual IRS expenditure on tax enforcement is positively related to aggregate financial reporting quality in the U.S. over the period 1965 to 2008. Specifically, we find that at the aggregate level, accruals better map into cash flows and the magnitude of discretionary accruals is lower in periods when tax enforcement is higher. The time-series test 
using aggregate IRS expenditures and the test using the Russian setting originally used by Desai et al. (2007), complement our analyses based on TRAC data.

This paper contributes to the literature arguing that tax enforcement serves as a corporate governance mechanism. Desai et al. (2007) argue that stricter tax enforcement makes it harder for insiders to extract private benefits, and hence, active monitoring by tax authorities protects the interests of outside shareholders. Consistent with their argument, Guedhami and Pittman (2008) and El Ghoul et al. (2011) show that an increase in tax authority enforcement leads to a reduction in the cost of debt and equity capital. We build on this literature by providing evidence that tax enforcement is associated with the quality of financial reporting. To the extent tax enforcement improves financial reporting quality, which in turn reduces information asymmetry, we provide evidence of a mechanism by which stricter tax enforcement leads to a reduction in the cost of capital as suggested by Guedhami and Pittman (2008) and El Ghoul et al. (2011). While our evidence supports the interesting hypotheses put forth by prior literature (e.g., Desai, Dyck and Zingales 2007, and Desai and Dharmapala 2009), we recognize that further research is necessary to confirm the validity of the theories in that literature. We look forward to such future research.

Our findings also contribute to the literature on the determinants of financial reporting quality and how the relation between accounting standards and reporting outcomes depends on country level institutions. For example, Leuz, Nanda, and Wysocki (2003) show that earnings management behavior varies with the extent of investor protection. Lang, Raedy, and Wilson (2006) compare the properties of U.S. GAAP reporting outcomes for U.S. firms and foreign firms cross-listed in the U.S. and show that the quality of U.S. GAAP earnings numbers is higher for U.S. firms than for cross-listed firms. They argue that foreign firms are subject to lower public and private enforcement which is part of the reason for the observed difference. Our paper 
builds on this literature by providing evidence that tax enforcement has an effect on financial reporting outcomes. ${ }^{2}$

The rest of the paper proceeds as follows. Section 2 develops our hypotheses. Section 3 describes our sample and variables. Section 4 presents our main results. In Section 5, we conduct robustness checks to verify our main results. Section 6 concludes.

\section{Prior Research and Hypotheses Development}

Desai et al. (2007) argue that insider actions and the amount of taxes paid are determined in a game that involves three parties - the state, insiders, and outside shareholders. They further argue that each bilateral agreement has important effects on the third party and describe three such bilateral agreements. The first potential bilateral agreement, the most traditional, is that insiders and outsiders collude to avoid taxes. Chen and Chu (2005) and Crocker and Slemrod (2005) develop principal-agent models regarding this type of bilateral agreement (e.g., compensation contracts), resulting tax avoidance, and the effect of penalties.

The second potential bilateral agreement is the model Desai et al. (2007) propose where the tax authority and outside shareholders have similar incentives to monitor insiders. Because obfuscation of information can provide mechanisms to avoid taxes and divert rents, the external monitoring by the tax authority to increase tax collections has a spillover effect of reducing managerial diversion. The third potential bilateral agreement is the model of managerial "bribes" to the tax authority in which the tax authority "looks the other way" with regard to rent diversion in exchange for side payments, or perhaps higher tax payments. ${ }^{3}$ Note that the term diversion is to be interpreted broadly to include any action that is in the interest of managers but not in the interest of shareholders and the government. For example, manipulating earnings to increase

\footnotetext{
${ }^{2}$ Other examples from this literature include, Ball, Kothari, and Robin (2000), Ali and Hwang (2000), Ball, Robin, and Wu (2003), Leuz (2003), Bushman and Piotroski (2006), Bradshaw and Miller (2008), and Holthausen (2009).

${ }^{3}$ While outright "bribes" are not commonly thought to occur in the U.S. one potential example of this model is Erickson, Hanlon, and Maydew's (2004) evidence that some companies paid taxes on overstated, allegedly fraudulent earnings. In a statement on May 2, 2003 Sen. Charles Grassely stated that the overpayments of Federal income taxes "...made the IRS an unwitting accomplice to their fraud."
} 
current and future compensation paid out to managers is a pervasive and well documented form of managerial rent diversion that occurs at the expense of both shareholders and potentially the tax authority (see Dechow, Ge, and Schrand 2010).

The focus of Desai et al. (2007) and the current paper is the second model of bilateral agreements in which the outside shareholders and tax authorities have similar incentives to reduce rent diversion on the part of management. The theory underlying the model is that the government, like any other shareholder, has an interest in preventing insiders from siphoning corporate funds to obtain private benefits. An audit by the tax authority typically subjects the entire firm to close scrutiny by tax agents which imposes substantial costs on the firm in terms of managerial time and effort, and the potential for the discovery of improprieties at the firm. ${ }^{4}$ Therefore, a tax audit can potentially help discipline managers. In support of their theory, Desai et al. (2007; p. 619) quote President William H. Taft in 1909 saying "Another merit of this tax [i.e., the federal corporate excise tax] is the federal supervision which must be exercised in order to make the law effective over the annual accounts and business transactions of all corporations."

While the Desai et al. (2007) theory is intriguing, it is somewhat difficult to test empirically because measures of both tax enforcement and managers' diversion of firm value are necessary. Desai et al. (2007) go outside of the U.S. and examine a sample of Russian firms after a sharp increase in tax enforcement following the election of Vladimir Putin in 2000. The effects of the increase in enforcement were that tax payments increased, related party trades were curtailed, and tax haven entities were abandoned. Important to the interpretation that tax authorities reduce agency problems, shareholders of firms in the oil industry where tax enforcement increased the most appeared to approve of the increased enforcement, as stock

\footnotetext{
${ }^{4}$ For example, in the U.S., an IRS audit can entail interviews with employees, verifications of internal controls, interviews with suppliers or customers, tours of facilities, access to corporate board minutes and inspection of physical assets. In addition, §7601-7613 of the Internal Revenue Code provides some of the statutory support for the IRS's ability to carry out certain procedures during an audit, and the Internal Revenue Manual (IRM.4.10.3) has specific protocol for what an IRS auditor is able to do during an audit.
} 
prices for tax avoiding firms rose significantly around government enforcement actions. The authors also note that "The more astute local observers were quick to draw a causal link between increased tax enforcement and greater shareholder returns." (p. 605) Further, Desai et al. (2007) quote the Financial Times in reporting about the oil and gas firms after tax enforcement increased as stating that "They must also show the true extent of their financial operations to outside shareholders, who are just as keen to have a share of the proceeds as the tax inspector" (p. 606; A. Jack, Financial Times, September 17, 2001). However, Desai et al. (2007) do not examine financial reporting quality in their tests.

Guedhami and Pittman (2008) uncover a seldom used data set about tax enforcement in the U.S. and use these data to examine the link between tax authority enforcement and the cost of debt capital for U.S. private firms. They hypothesize and find that tax authority enforcement mitigates agency problems between controlling shareholders and outside investors leading to cheaper debt financing. Further, they find that this effect is stronger when agency problems are expected to be greater (i.e., high ownership concentration). Thus, Guedhami and Pittman (2008) examine the Desai et al. (2007) theory in a U.S. setting providing a significant incremental contribution by identifying a proxy for tax enforcement in the U.S. and for identifying a setting where expectations of the effect of tax enforcement would be greatest - for private firms where other monitoring mechanisms (e.g., equity markets, the SEC) do not apply as strongly.

El Ghoul et al. (2011) extend the tests to large publicly traded firms in the U.S. and test the equity (rather than debt) cost of capital and report similar results - i.e., increases in tax enforcement are associated with lower costs of capital. Both studies provide evidence consistent with the Desai et al. (2007) theory of an implicit bilateral agreement between outsiders and the tax authority such that tax authority enforcement benefits outside stakeholders even after tax payments increase because of the reduction in managerial rent diversion. However, the precise mechanisms behind how tax authority enforcement affects information asymmetry and the cost 
of capital have not been examined. We conjecture that one way tax authority enforcement helps mitigate information asymmetry between insiders and outsiders is by improving financial reporting quality.

There are at least three potential avenues through which increased tax enforcement can lead to an improvement in financial reporting quality. First, while there are many differences between book and taxable incomes in the U.S., the two systems are at a basic level aligned. The calculation of taxable income is a hybrid of cash basis and accrual basis methods that does not allow companies to estimate expenses prior to the cash payment or defer revenue received until it is earned. Indeed, it is well documented that firms often face a trade-off between book and taxable incomes (Shackelford and Shevlin 2001; Hanlon and Heitzman 2010). Thus, to the extent that book and taxable incomes are aligned and to the extent that taxable income reporting is changed by greater tax enforcement, financial reporting will be changed as well. ${ }^{5}$ For example, one mechanism through which increases in tax enforcement can help improve reporting quality is by reducing accrual manipulation. Specifically, prior research finds that tax enforcement reduces incentives to understate taxable income (Hoopes et al. 2012), which is likely to reduce any downward bias in earnings due to the effect of conforming accruals. Further, prior research finds that a greater book-tax difference increases the likelihood of a tax audit (Mills 1998). Therefore, firms are less likely to use non-conforming accruals to increase book income because they increase book-tax differences and thus further increase the probability of a tax audit (Philips, Pincus, and Rego 2003; Badertscher, Phillips, Pincus, and Rego 2009). ${ }^{6}$

\footnotetext{
${ }^{5}$ See Scholes, Wilson, and Wolfson (1992), Guenther (1994) and Maydew (1997) for examples of studies that use financial accounting income measures as a proxy to observe taxable income shifting.

${ }^{6}$ Note that the tax authority is more likely to care about firms that understate taxable income than firms that overstate book income. However, ex ante, the tax authority cannot distinguish between firms understating taxable income and firms overstating book income by observing book-tax differences. Thus, greater book-tax differences caused by overstating book income and understating taxable income are likely to increase the probability of a tax audit. Our premise is that firms are averse to having a tax audit irrespective of whether they understate taxable income or not and thus are less likely to engage in actions that increase book-tax differences.
} 
Second, Desai et al. (2007) argue that many tax avoidance mechanisms require complexity and obfuscation to circumvent tax rules and to prevent detection. If tax enforcement reduces tax avoidance, it will also reduce any information obfuscation associated with tax avoidance activities. Specifically, stricter tax enforcement by tax authorities may reduce transactions and corporate structures aimed at diverting corporate value towards insiders (and saving taxes) and consequently, might reduce the ability of managers to obfuscate information, thereby leading to better financial reporting quality. For example, Dyreng, Hanlon, and Maydew (2012) find that firms are more likely to manage their foreign (pre-tax and after-tax) earnings when their subsidiaries are located in tax havens. Their premise is that managing earnings in tax havens avoids cash tax payments as well as the accounting income tax expense in most cases. Their evidence is consistent with a tax avoidance strategy - i.e., locating a subsidiary in a tax haven - allowing firms additional opportunities to manage earnings. It follows that increased tax authority scrutiny may then lead to lower tax haven usage, and as a result, fewer opportunities to manage earnings. Graham, Hanlon, Shevlin, and Shroff (2014) provide survey evidence consistent with this intuition.

Finally, as stated in Erickson et al. (2004) the detection of financial accounting misreporting would most likely come from outside analysts, investors, or the SEC, however, it could also come from the tax authority (the IRS in this case). Specifically, §6103(i)(3) of the Internal Revenue Code permits the IRS to disclose certain otherwise confidential tax information to other federal agencies if the information may constitute evidence of a violation of any Federal criminal law (not involving tax administration). While to our knowledge there is no reported case of the IRS reporting financial misreporting to the SEC, additional IRS enforcement could nevertheless be a potential deterrent to such financial accounting misreporting. ${ }^{7}$ In addition, even

\footnotetext{
${ }^{7}$ While we do not know if these are cases where the IRS tipped the SEC, Dechow, Ge, Larson, and Sloan (2011) find eight examples of AAERs in their sample that mention that the firm or the executives also have investigations
} 
if the IRS does not directly go to the SEC with information about potential accounting irregularities it discovers as part of its audit, the boards of directors are likely to be aware of the outcome of IRS audits during the regular course of business. As a result, the board may take action against managers for any earnings management or wealth diversion that takes place along with tax avoidance activities. The above reasoning leads to our first hypothesis stated as follows:

\section{H1: Tax authority enforcement is positively associated with financial reporting quality.}

An important assumption embedded in our first hypothesis is that firms are unable to fully resolve agency problems using governance mechanisms such as the board of directors and thus managerial diversion occurs in equilibrium. This assumption is supported by a number of prior studies (e.g., Armstrong, Guay, and Weber 2010 and Shleifer and Vishny 1997). Nevertheless, an implication of the above observation is that tax enforcement is more valuable and is likely to have a larger effect on financial reporting quality when agency problems are severe and managerial diversion is more likely. Specifically, in the absence of controlling shareholders capable of monitoring and disciplining managers, tax enforcement is likely to play an enhanced role in constraining managerial diversion. Consistent with this observation, Guedhami and Pittman (2008) and El Ghoul et al. (2011) find that the relation between tax authority enforcement and the cost of capital is stronger for firms experiencing worse agency problems. We examine whether tax enforcement has a stronger effect on reporting quality in environments where managers have more opportunities to divert wealth.

H2: The positive association between tax authority enforcement and financial reporting quality is higher when other external monitoring mechanisms are weaker.

underway by the Criminal Division of the IRS. For example, AAER \# 1776 states "This action was brought in close coordination with the U. S. Attorneys' Office in Tulsa, Oklahoma and the Internal Revenue Service-Criminal Investigation Division, which simultaneously announced Patterson's indictment and arrest on related criminal securities fraud charges and bank and tax fraud charges" and AAER \# 1797 states, "The Commission acknowledges the assistance to its investigation of the United States Attorney for the Southern District of Texas, the Federal Bureau of Investigation, the United States Postal Inspection Service and the Internal Revenue Service." We thank Weili Ge for sharing these examples with us. 
We note that our tests of $\mathrm{H} 1$ and $\mathrm{H} 2$ assume that companies are cognizant of the expected level of tax authority enforcement. Firms can only respond to the level of tax enforcement to the extent that they are aware of tax authority's activities. We conjecture that firms can obtain information and develop expectations about the level of tax enforcement through a variety of channels. In the U.S., information about proposed IRS budgets and historical budgets are a matter of public record and are also covered in the press. Financial resources allocated to the IRS provide important information about the level of enforcement to expect. Similarly, news about structural changes in the IRS or leadership changes at the IRS that affect the level of enforcement may also be informative to firms. ${ }^{8}$ Firms also obtain information about IRS activities by hiring former IRS employees, by maintaining contact with former employees who currently work at the IRS, and through formal and informal meetings with IRS officials. ${ }^{9}$

In some cases the IRS even makes statements suggesting an increase in audit rates. For example, an article on CFO.com entitled IRS to Audit more $S$ Corporations states, "The IRS plans to examine later this year 5,000 randomly selected S corporation returns from the 2003 and 2004 tax years (Schneider 2005).” Blank and Levin (2010) argue that IRS officials deliberately use tax enforcement publicity to influence individual taxpayers' perceptions and knowledge of audit probability, tax penalties, and the government's tax enforcement efficacy while taxpayers are preparing to file their tax returns. Other sources of information about IRS enforcement

\footnotetext{
${ }^{8}$ For example, when Mark Everson replaced Charles Rossotti as the IRS commissioner in May, 2003, he brought about a significant shift in the vision of enforcement at the IRS. According to a brief history of the IRS produced by the Transactional Records Access Clearinghouse, "The initial vision of the two men about the role of IRS agency was quite different. Rossotti...had sought to lead the agency away from its heavy emphasis on enforcement...Almost from the first day of Everson's five-year term, his official statements have reflected the belief that tougher enforcement was required to recover the 'many billions of dollars of lost tax revenues.'...The commissioner then outlined his priorities, starting with a focused attack on the corporations and high income taxpayers who did not abide by the law (TRAC 2005)."

${ }^{9}$ For example, PricewaterhouseCoopers issued a press release in 2006 announcing the appointment of a new managing director in their Washington National Tax Service, a 35 year veteran of the IRS's Large and Medium Sized Business (LMSB) division (PricewaterhouseCoopers 2006). As further evidence, an article in Accounting Today (1996) starts off with "Yet another Internal Revenue Service Official has jumped back to the private sector." Furthermore, anecdotal evidence suggests that hiring such people from the Service is not uncommon. GE's tax department's mission statement includes a point to "ensure that the tax team has as many former government tax experts as possible" (Larsen, Beran, D’Avino, and Hawkins 2007).
} 
include trends in government revenue, news about historical annual and monthly audit coverage released by the IRS, and organizations such as TRAC that have a self-proclaimed mission of monitoring IRS activities. Overall, we conjecture that information about the level of tax enforcement can be obtained from a number of sources. Hoopes et al. (2012) find support for this conjecture by surveying 50 tax directors, and finding that $72 \%$ claim to assess and consider the probability of a tax audit when making tax related decisions.

\section{Sample Selection, Descriptive Statistics and Research Design}

\subsection{Sample Selection}

To select our sample we start with all firm-year observations in Compustat between 1992 and 2008 with data on total assets. The availability of TRAC data (see Appendix A) limits our sample to the period 1992, and we end our sample in 2008. We also require firms to be incorporated in the U.S. and be headquartered in one of the 50 states or the District of Columbia. Firms incorporated or headquartered outside the U.S. are subject to lesser IRS scrutiny since a greater proportion of their operations are located abroad; hence we exclude them from our analysis. We limit our sample to C-corporations because the IRS enforcement data applies only to these firms (the IRS maintains different statistics for trusts, partnerships, and S-Corporations). We eliminate utilities and financial firms (SIC codes 4900-4999 and 6000-6999) because they have significantly different incentives due to regulatory concerns and because our measures of financial reporting quality are not designed for this type of firm. Finally, data requirements for

our control variables and financial reporting quality measures further limit the sample. Our final sample consists of 46,338 - 64,982 firm-year observations depending on the measure of financial reporting quality employed (see Table 1).

\subsection{Empirical Specification}

We examine the empirical relation between financial reporting quality and tax authority enforcement by estimating the following least squares regression: 


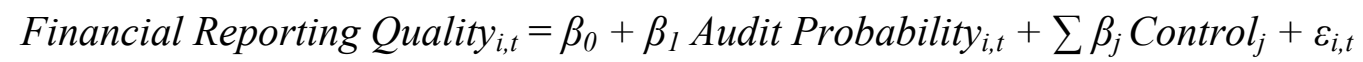

where Audit Probability is the likelihood of receiving an IRS audit (described in section 3.4) and Controls is a vector of controls (described in section 3.5). We include firm and year fixed effects in each of our regressions and cluster standard errors by firm. The inclusion of firm fixed effects removes any unobservable stationary firm specific component of reporting quality and year fixed effects captures systematic changes in reporting quality for all firms in a given year (i.e., crosssectional correlation). We cluster standard errors by firm to allow for the possibility that unobservable firm characteristics cause residual correlation for firms across years.

\subsection{Measuring Financial Reporting Quality}

We employ the following two measures of financial reporting quality: i) the mapping of accruals into cash flows (i.e., accrual quality, Dechow and Dichev (2002) and McNichols (2002)), and ii) a measure of discretionary accruals developed by Jones (1991) and Dechow et al. (1995). Appendix B provides a detailed description of the variable construction process.

A primary role of accruals is to overcome problems with measuring firm performance by shifting the recognition of cash flows over time, so that the adjusted numbers (earnings) better measure firm performance. However, accruals are generally based on assumptions and estimates that can be made with error or affected by managerial opportunism. An underlying assumption in the earnings quality literature is often that firms likely have "abnormal" accrual activity when managers make incorrect (erroneous or opportunistic) accrual accounting assumptions.

Discretionary accruals is a proxy for abnormal accrual activity based on a specific assumption of what constitutes 'normal accruals.' Specifically, discretionary accrual models assume that accruals are a linear function of sales growth and property, plant, and equipment and that deviations from the model are likely due to opportunism. We employ this measure in our tests with the intent of examining any changes in accounting accrual reporting as a result of increased tax enforcement. In our tests, we use the absolute value of discretionary accruals (i.e., 
unsigned accruals) because accruals can include positive and negative estimation errors and can be used opportunistically to inflate or reduce earnings (e.g., big bath, cookie jar reserves, etc.).

We supplement the measure of abnormal accrual activity with a measure designed to assess the quality of accrual accounting assumptions and estimates. Specifically, we use the Dechow and Dichev (2002) measure of accrual quality which assesses the degree to which current accruals map into last-period, current-period, and next-period cash flows. The DechowDichev measure is predicated on the assumption that the matching function of accruals to economic performance is of primary importance. Thus, when abnormal accruals are used to communicate managers' private information we expect the Dechow-Dichev accruals quality measure to be higher than if abnormal accruals are estimated in error or used to obfuscate information (i.e., private information in accruals will map to future cash flows more so than would accruals from either of the other two sources - error or manipulation). Therefore, we expect our two measures of reporting quality to complement each other and strengthen our inferences about the relation between tax authority enforcement and reporting quality. ${ }^{10}$

To better understand the manner in which tax authority enforcement might affect our specific proxies for financial reporting quality, consider the following stylized example. Firms are more likely to use complex tax shelters to avoid taxes when tax enforcement is low. Further, complex tax shelters are likely to create greater tax risk and thus result in larger contingent tax reserves. The larger the contingent tax reserve, the greater the opportunity for managers to make adjustments to this accrual such that they report higher or lower earnings to extract private benefits. To the extent there is manipulation of the contingent tax reserve, this accrual will be (i)

\footnotetext{
${ }^{10}$ In untabulated analyses, we also examine the effect of changes in tax enforcement on earnings informativeness (i.e., ERCs) as measured by the relation between stock returns and changes in earnings and changes in earnings interacted with changes in audit probability. However, pre-post long-window earning informativeness tests are not as suited in our setting because we do not have a clear pre- and post-window. In addition, an earnings informativeness test in our setting requires the additional assumption that the markets' and managers' expectations about tax enforcement are aligned. Nevertheless, we use earnings informativeness as a third measure of reporting quality and note that our inferences are unchanged.
} 
less likely to map into cash flows (in a Dechow and Dichev type model) and (ii) more likely to be an outlier in the Jones (1991) type model.

While the above example is highly stylized, we note that more concrete examples of our hypothesized relation based on real life events are hard to come by because this requires us to identify firms that managed earnings and got caught, and simultaneously show that the earnings management would not have taken place absent tax avoidance behavior. However, prior research provides some (necessarily egregious) examples along these lines. We refer the interested reader to Desai (2005) and Desai and Dharmapala (2006, 2009). These papers describe detailed examples of an interaction between tax avoidance and financial reporting behavior from Dynergy, Tyco, Parmalat, Xerox, and Enron. Specifically, the examples suggest that tax avoidance activities gave additional opportunities for earnings management. Basically, our intuition is that an increase in tax authority enforcement reduces the likelihood of engaging in tax avoidance behavior and consequently, an increase in tax authority enforcement might also have an (indirect) effect on earnings management behavior, thus affecting financial reporting quality.

\subsection{Measuring Tax Enforcement}

Our independent variable of interest is the probability of an IRS audit measured by the ex-post realizations of actual face-to-face audits. These data are obtained from the Transactional Records Access Clearinghouse (TRAC), a non-profit entity which uses Freedom of Information Act requests and lawsuits to access information directly from the IRS (see Appendix A). The IRS maintains records of audits completed and returns received for every IRS district by firm size (based on total assets) each year. ${ }^{11}$ Therefore, the variation in audit probability is induced by firm size, location, and fiscal year and we exploit this variation by measuring audit probability in three ways. The first measure, Size/Time Audit Probability, is the number of IRS audits completed in a given year for a given asset size group divided by the number of returns received

\footnotetext{
${ }^{11}$ The IRS maintained district level data until 2000. When the IRS reorganized in 2000 the district level data was no longer collected.
} 
in the previous year for the same asset size group. Because Size/Time Audit Probability varies only with firm size and year we cannot unambiguously attribute a relation between Size/Time Audit Probability and our reporting quality proxies as evidence that IRS enforcement affects reporting quality. Specifically, if reporting quality varies with firm size and year in the same manner in which IRS audit probability varies with firm size and year we cannot distinguish the effect of the changes in tax enforcement on reporting quality from the effect of firm size and year on both IRS audit rates and the reporting quality measures.

The second measure we employ, District/Size/Time Audit Probability, consists of the IRS audit rate data aggregated by district, firm size, and year. That is, we assign audit probabilities for each firm based on the firm's location (i.e., the IRS district proxied for by the location of its headquarters), assets, and fiscal year. Our third measure, District/Time Audit Probability, consists of data aggregated only by IRS district each year and hence, is not directly related to firm size (see Appendix A for detailed discussion of the measures). ${ }^{12,13}$

It is important to note that the ideal measure of tax enforcement for our research question is not the actual probability that a firm will be audited (as determined by the tax authority). Rather, it is the managers' perception of the probability of an audit. Therefore, even if our measure of audit probability from TRAC data does not accurately capture the actual probability of an audit for an individual firm, as long as it is correlated with managers' perceived probability

\footnotetext{
${ }^{12}$ Prior research suggests two alternative reasons for the variation in IRS audit intensity across districts. Geographic variation in audit probability occurs either because of the IRS's inability to efficiently and appropriately allocate resources (Beron, Tauchen, and Witte 1992) or because the IRS efficiently allocates resources based upon predicted geographic patterns in tax evasion (Slemrod and Yitzhaki 2002). Regardless of why the IRS allocates more resources to different areas at different times, as long as that reason is not directly related to financial reporting quality, exploiting this variation for our purpose is justified.

${ }^{13}$ One potential concern with our empirical specification is that our dependent variable is measured at the firm-year level but our independent variables of interest (i.e., tax audit probabilities) are measured at an aggregate level by firm-size groups and year. As a result, it is plausible that the error terms in our regressions are not conditionally independent and there is residual correlation within size-groups and/or within years. To address this concern, we examine the robustness of our results to clustering the standard errors (i) by year, (ii) two-way clustering by firm and year, and (iii) two-way clustering by asset class and year. We find that our results are robust to clustering in these three different ways. Further, we also verify the robustness of our inferences to aggregating the dependent variables by each size-group and year, and estimate a regression at the aggregate-level. Our inferences remain unchanged.
} 
of being audited, our tests should be able to identify the relation between tax enforcement and reporting quality.

The IRS audit rates for corporations are displayed in Figure 1, Panel A. The figure makes apparent that there is considerable variation in audit coverage across size groups and time. For example, 55.6 percent of the firms with assets exceeding \$250 million were audited by the IRS in 1992. This fraction fell to 30.5 percent in 2000 before increasing to 42.6 percent in 2005 and then falling again to 26.7 percent in 2008. However, except for the years 2000 to 2002 and 2003 to 2005 , there has been a declining trend in IRS enforcement since 1992. Therefore, besides including year fixed effects in all our regressions, we conduct a series of robustness tests to ensure that our results are not driven by the declining trend in IRS audits. ${ }^{14}$ Figure 1, Panels B and $\mathrm{C}$, present our proxies for financial reporting quality by each IRS asset size group over time. Here again, we see that there is considerable variation in both measures of reporting quality. However, there is no visible trend in the data as observed in the IRS audit probabilities.

\subsection{Other Control Variables}

As with most papers that study financial reporting quality, the measures we consider are jointly determined by fundamental factors, such as firms' operating environments and by management's discretionary reporting and implementation decisions. The discretionary reporting and implementation choices are affected by incentives to obfuscate information, incentives to provide private information, forecasting errors, and errors in implementing accounting rules; we do not attempt to separate these discretionary effects.

However, since we are interested in identifying the effect of tax authority enforcement on the discretionary choices made my management, we attempt to control for the influence of the operating environment following Francis, LaFond, Olsson, and Schipper (2005) by including the

\footnotetext{
${ }^{14}$ The very largest corporations in the U.S. are under continuous audit as a result of being classified by the IRS as Coordinated Industry Case (CIC) firms. Since these firms in effect have an audit probability that approaches one, we re-set the values of all three measures of Audit Probability to 1 for the firms likely to be in the CIC program in our analyses (we thank Joel Slemrod for this suggestion). However, we note that the inferences from our tests are unchanged albeit statistically weaker when we do not make this correction. See Appendix A for further discussion.
} 
following covariates in our regression: firm size, standard deviation of cash flows from operations, standard deviation of sales, length of operating cycle, capital intensity, intangible asset intensity, a binary variable for the presence of intangible assets, and the proportion of times the firm has realized negative earnings in the preceding ten years. ${ }^{15}$ Besides business fundamentals, we also control for leverage, profitability, and growth opportunities in our regressions since prior research shows that these characteristics are associated with incentives to manage earnings (see Dechow et al. 2010). All variables used in our analyses are defined in Appendix B. Lastly, we also control for firm- and year-fixed effects in all our regressions to allow for the possibility that unobservable firm or year characteristics are correlated with both reporting quality and our IRS enforcement proxies. ${ }^{16,17}$

SEC enforcement is also likely to be an important determinant of reporting quality. However, the only measures of SEC enforcement that we are aware of are either at an annual level (e.g., SEC's annual budget, number of employees, etc.) or at a firm-level (e.g., proximity to an SEC office) both of which are subsumed by year- and firm-fixed effects. In an attempt to directly control for SEC enforcement, we compute the distance from the nearest SEC regional office to the firm's headquarters (a firm-fixed measure) and interact this distance variable with the SEC's annual budget (a year-fixed measure). We employ distance to the nearest SEC office (times -1 to get a measure of proximity) under the theory that the closer the SEC office the greater the monitoring by the SEC (Kedia and Rajgopal 2011) and because it provides a firmlevel measure to interact with a year measure from the SEC.

\footnotetext{
${ }^{15}$ Hribar and Nichols (2007) show that unsigned earnings quality metrics such as the absolute value of discretionary accruals are systematically related to the variance of the underlying error term in the $1^{\text {st }}$ stage regression, which leads to biased inferences. They go on to show that controlling for the standard deviation of sales or cash flows mitigates potential biases. We control for these variables in our regressions.

${ }^{16}$ In untabulated tests, we find that our inferences are robust to controlling for the Big 4 auditors. However, since firms rarely change auditors, the inclusion of firms fixed effects subsumes the control for auditors.

${ }^{17}$ In untabulated tests, we find that our inferences are robust to controlling for manager-fixed effects in addition to firm-fixed effects. Our intuition for this test is to mitigate concerns that quality of management, personnel training and expertise, record-keeping processes, internal controls, etc. confound our inferences. Our inference also remains unchanged if we estimate the model using a first difference test design.
} 


\subsection{Descriptive Statistics}

Table 2 Panel A presents descriptive statistics for our variables. The mean (median) values for Accrual Quality and Discretionary Accruals are -6.95 (-4.75), and $0.15(0.09)$, respectively. The distributions of our reporting quality measures are similar to that found in prior research (e.g., Doyle, Ge, and McVay 2007). The mean (median) probability of audit measured by Size/Time Audit Probability for our sample is 40\% (22\%). Guedhami and Pittman (2008) report a mean (median) audit probability of 27.4\% (29\%) for their sample of private firms. Since private firms are smaller than public firms and audit probabilities increase with firm size, this is consistent with expectations. Also note that there is considerable variation in the measures of audit probability and the probabilities are sufficiently high to warrant attention by firms. For example, the inter quartile range for District/Size/Time Audit Probability is 0.41 indicating that a firm's likelihood of receiving an IRS audit increases by 41 percentage points when it moves from the $25^{\text {th }}$ to the $75^{\text {th }}$ percentile of the District/Size/Time Audit Probability distribution.

The average firm has Assets worth $\$ 1.22$ billion, a Market to Book ratio of 1.93, long term debt (Leverage) equal to $21 \%$ of assets. Further, the average firm realized losses $37 \%$ of the time in the past ten years and the median Return on Assets is 2\%. These statistics are largely consistent with those reported in Francis et al. (2005). However, the firms in our sample, on average, have a greater proportion of losses (37\% vs. 19\%) and higher standard deviation in sales (0.42 vs. 0.26$)$, as is expected given our later sample period where more losses are known to occur (Fama and French 2004; Skinner 2008). ${ }^{18}$

Table 2 Panel B presents the pairwise Pearson (Spearman) correlation coefficients below (above) the diagonal for our variables. The table shows that Accrual Quality and Discretionary

\footnotetext{
${ }^{18}$ The large proportion of losses raises the question whether loss firms respond to IRS enforcement differently than non-loss firms. While we include a control for losses in all our regressions (Negative Earnings), in untabulated analysis, we also estimate the regressions in Table 3 on only firms without losses, and find results consistent with our prediction. In these models, the coefficient and t-statistic for Size/Time Audit Probability is smaller than that in the full sample of firms (but significant at the two-tail 10\% level or better). The smaller coefficient for profitable firms is not consistent with our expectations about the effects of IRS audits on profit versus loss firms.
} 
Accruals have a Pearson correlation coefficient of $-0.47 .{ }^{19}$ The correlation coefficient for our measures of reporting quality suggest that the measures are different from each other and they likely capture different attributes of reporting quality consistent with the observation in Dechow et al. (2010). ${ }^{20}$ These univariate relations also reveal a positive correlation between our measures of IRS audit probability and Accrual Quality and a negative correlation between our measure of IRS audit probability and Discretionary Accruals, consistent with H1. The remaining correlation coefficients are consistent with expectations and prior research (e.g., Doyle et al. 2007; Francis et al. 2005). For example, the Market Value of Equity (In(MVE)), Return on Assets, and Institutional Investors, are positively correlated with Accrual Quality and negatively correlated with Discretionary Accruals. In addition, SD Cash Flows, Operating Cycle, and Intangible Intensity are negatively correlated with Accrual Quality and positively correlated with Discretionary Accruals. All correlation coefficients reported in the table are statistically significant at the $5 \%$ level or better.

\section{Empirical Results}

\subsection{Tests of H1: Baseline Specification}

We begin our analysis of testing $\mathrm{H} 1$ using the primary measure of audit probability in the TRAC data, the Size/Time Audit Probability. Table 3 presents the results of estimating equation (1) for each of our measures of financial reporting quality. As the data reveal, the coefficient for Size/Time Audit Probability is significant and in the predicted direction in each of the regression estimations. These results are consistent with $\mathrm{H} 1$ that greater tax authority enforcement is positively associated with financial reporting quality. ${ }^{21,}{ }^{22}$ In terms of economic importance we

\footnotetext{
${ }^{19}$ Doyle et al. (2007) report a correlation coefficient of 0.58 similar to our 0.47 (we alter the sign in our variable).

${ }^{20}$ Specifically, Dechow et al. (2010) find that the various measures of earnings quality are not highly correlated with each other, and also note that the measures are not substitutes for each other because they are not equally affected by the fundamental and discretionary components of financial reporting quality. Also see Ewert and Wagenhofer (2010).

${ }^{21}$ In untabulated analyses, we also find that changes in IRS enforcement are associated with an improvement in earnings informativeness (i.e., the long window relation between earnings changes and stock returns).
} 
find that a ten percent increase in Size/Time Audit Probability decreases Discretionary Accruals $(D A)$ by 0.73 percent, ceteris paribus. Similarly, we find that a ten percent increase in Size/Time Audit Probability is associated with a 0.40 percent increase Accrual Quality $(A Q) .{ }^{23}$

The control variables are also generally consistent with expectations. Specifically, higher values for the market to book ratio, leverage, operating cycle, frequency of negative earnings, and the standard deviation of sales lead to an increase in $D A$ and a decrease in $A Q$. Further, market value of equity (ln $M V E$ ) and $R O A$ are negatively (positively) related to $D A(A Q)$ while the relation between $\ln M V E$ and $D A$ is statistically insignificant.

Surprisingly, we find that our proxy for SEC enforcement - the interaction between SEC proximity and SEC budget - is not significantly related to $A Q$ or $D A$. To investigate further and reduce the likelihood that we are incorrectly attributing the effect of SEC enforcement to IRS enforcement, we examine whether proxies for SEC enforcement are correlated with those for IRS enforcement at an aggregate level. We find that the correlation between the IRS and SEC annual staffing levels and their annual budgets are statistically insignificant, thereby mitigating the concern that SEC enforcement is a correlated omitted variable in our regressions. While the absence of a relation between reporting quality and SEC proximity is inconsistent with Kedia and Rajgopal (2011), we note that unlike in Kedia and Rajgopal (2011), SEC proximity enters as an interaction term in our regressions since the main effect of SEC proximity is subsumed by firm fixed effects. Further, Dyreng et al. (2012) also find that the distance to the nearest SEC office is not significantly related to reporting quality when employed as a control variable.

\footnotetext{
${ }^{22}$ Since we examine the contemporaneous association between IRS audit probability and financial reporting quality, our tests assume that managers have rational expectations of the actual IRS audit rates. However, in untabulated tests we relax this assumption and use the audit rates from one and two prior years as the proxy for the manager's perceived probability of an IRS audit in all our analyses. We find that our results are robust to this change.

${ }^{23}$ We compute economic magnitudes by estimating the effect of a $10 \%$ increase in audit probabilities on the percentage change in the dependent variable from its conditional mean. Specifically, we compute the magnitude of our result by estimating our regression and using the actual data to predict a value of $\mathrm{Y}$ ( $\left.\mathrm{Y}_{\text {Actual }}\right)$ for all observations. We then increase the value of Audit Probability by 10\%, and, using the coefficient estimates from the original regression, predict $\mathrm{Y}$ again $\left(\mathrm{Y}_{\text {increase }}\right)$, reflecting the effect a 10\% change in Audit Probability would have on $Y$. The percentage difference between the mean value of $Y_{\text {Actual }}$ and $Y_{\text {increase }}$ is the effect of a $10 \%$ change in Audit Probability on Y.
} 


\subsection{Tests of H1: Use of Geographic Audit District Probability}

We next employ additional measures of IRS audit probability to examine our research question and hypotheses. These additional measures are relatively less correlated with firm size and time. The first measures we employ are District/Size/Time Audit Probability and District/Time Audit Probability, both of which vary by audit district. The results in Table 4 show that both variables are significantly negatively related to $D A$ (coefficients of -0.021 and -0.015 , both significant at the 0.01 level). Both geographic audit probability measures, District/Size/Time Audit Probability and District/Time Audit Probability, are positively related to $A Q$ as well (coefficients of 0.742 and 0.226 , respectively). However, only District/Size/Time Audit Probability is statistically significant conventional levels; District/Time Audit Probability has a p-value of 0.12 (one-sided). Overall, the coefficients again suggest that higher levels of tax authority enforcement are associated with lower $D A$ and higher $A Q$, which is consistent with our first hypothesis. Similar to the results in Table 3, the control variables generally line up consistent with prior research. We interpret the results in Tables 3 and 4 as suggesting that tax authority enforcement is associated with higher financial reporting quality. ${ }^{24}$

\subsection{Test of H2: The Effect of Other Monitoring Mechanisms}

We next examine cross-sectional variation in the relation between tax authority enforcement and financial reporting quality conditioned on the extent to which other monitoring mechanisms are present $(\mathrm{H} 2)$. We predict that in the presence of other monitoring mechanisms, tax authority enforcement is less likely to have an incremental effect in limiting managerial diversion. We measure the presence of external monitors as the level of institutional ownership and proportion of dedicated institutional investors. We use the proportion of dedicated

\footnotetext{
${ }^{24}$ In untabulated analyses, we verify the robustness of our inferences with seven measures of annual IRS enforcement that are used by Guedhami and Pittman (2008). The seven year-level proxies for tax enforcement include 1) the number of IRS criminal investigation referrals, 2) the number of corporate tax prosecutions, 3) the number of corporate civil penalties due to fraud, 4) the number of corporate civil penalties due to negligence, 5) the number of IRS permanent employees, 6) the number of IRS revenue agents, and 7) the number of IRS criminal investigators. We find that our inferences are robust to using all seven measures of IRS enforcement. Specifically, we find that the coefficient for IRS enforcement is positively associated with $A Q$ and negatively associated with $D A$ at conventional levels of statistical significance using all seven IRS enforcement measures.
} 
institutions to focus on those that will monitor manager behavior (Bushee 1998). Prior research shows that dedicated institutions play a role in disciplining managers and mitigating agency problems (see Armstrong et al. (2010) for a review).

To test $\mathrm{H} 2$, we include these measures and an interaction between these measures and tax authority enforcement as additional covariates in our primary regression. Table 5 reports the results. We find that tax authority enforcement is negatively related to $D A$ but the relation is weaker when institutional ownership and dedicated investor ownership is higher. Similarly, tax authority enforcement is positively related to $A Q$ but the relation is weaker when institutional ownership and dedicated investor ownership is higher. ${ }^{25}$ These results are consistent with $\mathrm{H} 2$ and suggest that tax authority enforcement has a weaker association with financial reporting quality in the presence of other monitoring mechanisms that reduce managerial wealth diversion.

\section{Tests of $\mathrm{H1}$ and $\mathrm{H} 2$ using a Different Setting and Alternative Data}

\subsection{Earnings Informativeness and Tax Enforcement Changes in Russia}

To further investigate our research question we return to the original setting in Desai et al. (2007) - the sudden increase in tax enforcement in Russia following the election of Vladimir Putin as Prime Minister in 2000. The 2000 election of Putin brought a sudden regime change in Russia. Upon his election, Putin signaled his intention to crackdown on tax evasion by releasing a memorandum with a list of the worst tax offenders. While some of these crackdowns later appeared to be politically motivated, initially they seemed designed exclusively to raise tax revenues that the government desperately needed (see Desai et al. (2007) for a detailed description of the unfolding of events in Russia). We use the sudden change in tax enforcement

\footnotetext{
${ }^{25}$ One potential concern with our tests of $\mathrm{H} 2$ is that our proxies for tax enforcement are highly correlated with institutional ownership (correlation coefficient $=0.51$ ), thus raising concerns of a multicollinearity bias. To examine whether the high correlation affects our inferences, we compute the variance inflation factors (VIFs) for institutional ownership in our regressions. We find that the VIFs range from 4 to 10 depending on the regression (i.e., the dependent variable and institutional investor type). VIFs above 10 can potentially bias inferences (Greene 2003) and thus we suggest caution interpreting these results.
} 
in Russia as a quasi-experimental setting to examine whether the financial reporting quality improved after the increase in tax enforcement.

The setting in Desai et al. (2007) has two desirable attributes for studying the effect of tax enforcement on financial reporting quality. First, the increase in tax enforcement was substantial and was well publicized. Therefore, firms knew of and had the opportunity to respond to the increase in tax enforcement. Second, the increase in tax enforcement was not part of a general desire to increase enforcement all around. Therefore, our tests are unlikely to be subject to the concern that auditing and financial reporting enforcement increased as well.

We use this setting to examine whether the reported earnings of Russian firms became more informative after the increase in tax enforcement. Ideally, we would like to examine whether $A Q$ and $D A$ changed following the increase in tax enforcement in Russia as we did in the U.S. setting. However, limited data availability precludes us from measuring reporting quality using $A Q$ and $D A$. Even when we impose minimal data requirements by requiring data only on stock returns, earnings, and total assets we are left with only 60 firm-year observations around the tax change to estimate our regressions. Therefore, we use long-window ERCs as the next best alternative to measure reporting quality. The long-window ERC test lends itself to the Russian setting (unlike the U.S. setting) because it has a clear pre- and post-period when tax enforcement changed, which makes lining up the accounting earnings, returns, and enforcement easier in empirical tests. Further, the tax enforcement change in Russia was well publicized making it very likely that this information was known to both managers and investors. ${ }^{26}$

Following Hanlon et al. (2008) and Badertscher et al. (2013), we measure earnings informativeness using the contemporaneous relation between stock returns and changes in earnings. We then compare the relation before the change to the relation after the change in tax enforcement, thus using the firm as its own control. To strengthen the test, we examine cross-

\footnotetext{
${ }^{26} \mathrm{We}$ also re-examine the effect of changes in tax enforcement on earnings informativeness in the U.S. as measured by the relation between stock returns and changes in earnings and changes in earnings interacted with changes in audit probability. The coefficient for the interaction term (changes in earnings interacted with changes in audit probability) is significant in the predicted direction further supporting Hypothesis 1 (untabulated).
} 
sectional differences in the expected effect of tax enforcement on earnings informativeness. Specifically, prior research shows that firms from countries with weak domestic institutions and corporate governance practices cross-list their equity in the U.S. to signal their commitment to strengthen corporate governance practices (Coffee 1999; Stulz 1999; Hail and Leuz 2009). Moreover, firms cross-listed on NASDAQ, NYSE, or Amex are required to comply with U.S. SEC disclosure rules. Therefore, Russian firms cross-listed in the U.S. are likely to have more informative earnings to begin with and the increase in tax enforcement should have a smaller effect on their earnings informativeness.

We test the above two predictions using stock returns and earnings data for the period 1998 to 2002 (excluding year 2000 since it is the year Putin was elected) from Compustat Global. We regress stock returns for firm $i$ in year $t$ on the change in earnings for firm $i$ from year t-1 to t. To test whether earnings informativeness increased after Putin was elected, we include an indicator variable for the period after Putin's election and interact the indicator variable with the change in earnings. The coefficient for the interaction term captures the change in earnings informativeness in the Putin era. Next, to examine cross-sectional differences in the change in earnings informativeness, we construct an indicator variable for firms without American Depositary Receipts (ADRs) and include a three way interaction of the change in earnings, the Putin indicator, and the non-ADR indicator. The coefficient for the three-way interaction term captures the incremental effect of the increase in tax enforcement on earnings informativeness for non-ADR firms. We estimate our regression with the least absolute deviation estimator (also known as median regressions). Median regressions enable us to control for the effect of outliers in the data even in small samples where winsorizing data are ineffective. However, we find that our results are unchanged when we use the OLS estimator.

Table 6 presents the results. The first column shows that the coefficient for the interaction of changes in earnings and the post Putin indicator is positive and significant. The coefficient indicates that earnings informativeness improved following the tax enforcement efforts of Putin. 
The second column in the table shows that the coefficients for the three-way interaction of changes in earnings, the post-Putin indicator, and the non-ADR indicator and the two-way interaction of changes in earnings and the post-Putin indicator are positive and significant. These two coefficients suggest that while earnings informativeness increases after the election of Putin, firms not cross-listed in the U.S. have the greatest increase in earnings informativeness. This cross-sectional variation is consistent with tax enforcement providing greater benefits for shareholders of firms with fewer other monitoring mechanisms.

\subsection{Aggregate Time-Series Evidence from 1965 - 2008}

We conduct one other test using non-TRAC data to corroborate our findings. We obtain annual IRS tax enforcement expenditures and examine whether the IRS spending on tax enforcement is associated with aggregate financial reporting quality over the period 1965 to 2008. We measure aggregate financial reporting quality using residuals from pooled DechowDichev and Jones model regressions for each Fama and French (1997) industry. The average absolute residuals each year from these regressions is our measure of financial reporting quality (specifically, the residual from the Jones model divided by the number of firms; the aggregate sum over the firms each year divided by the number of firms to account for firm entries and exits over our sample period). ${ }^{27}$ The results are presented in Table 7. The table shows that IRS expenditures are positively related to $A Q$ and negatively related to $D A$. Further, this relation is robust to controls for enforcement by the SEC, although the effect does weaken as one would expect. ${ }^{28}$ This result complements our other tests which show that tax enforcement is associated with better financial reporting quality. ${ }^{29}$

\footnotetext{
${ }^{27}$ See Kang, Liu, and Qi (2010) for a discussion of aggregate discretionary accruals. The authors state that aggregate discretionary accruals likely reflect aggregate fluctuations in earnings management.

${ }^{28}$ We scaled both IRS and SEC expenditure by total government expenditure to make the variables stationary.

${ }^{29}$ An important drawback of the data we use in this test is that SEC expenditures are net of the receipts from fines. Hence, if fines are significant, smaller values for the variable could either be less enforcement or more receipts from fines. For this reason, we suggest caution interpreting the results from this test.
} 


\subsection{Bootstrap Test}

Next, we conduct bootstrap tests to reduce concerns that our results are primarily driven by the declining trend in IRS audit probability. We begin by randomly assigning the audit probabilities in a year to each firm in that year without regard to firm size. Therefore, while the temporal trend in IRS enforcement is unaffected, the relation between asset size and IRS enforcement within each year is removed through this random assignment. We then estimate our main regression using the randomly assigned IRS enforcement variable. If the coefficient for IRS enforcement after the random assignment is statistically indistinguishable from (or larger than) the coefficient for IRS enforcement before any random assignment, is it possible that the results we document are on account of a temporal trend in our variables of interest. To compute statistical significance, we repeat the randomization procedure 1,000 times and compute the number of times the coefficient for IRS enforcement after the randomization procedure is as large as the coefficient for IRS enforcement before randomization. The ratio of these two numbers is our measure of statistical significance (see Noreen 1989 and Shroff et al., 2014).

We find evidence that our results are unlikely to be driven by the time trend in IRS enforcement. Specifically, we find that in fewer than 25 of the 1000 regressions the coefficient for the IRS enforcement variable is greater than the coefficient achieved using the actual sample for both our financial reporting quality measures (untabulated results). This provides further evidence that the downward trend in IRS enforcement is unlikely to be driving our results.

\subsection{Analyses within Sub-Periods}

To further alleviate the concern that the time trend in IRS audit rates drives our results, we examine whether our inferences are robust to estimating a separate coefficient for our audit probability variable for each year in our sample. Specifically, we repeat our main analyses after interacting the vector of year indicators with our proxy for audit probability. We find that the coefficient for our audit probability proxy is statistically significant in 15 (12) of the 17 (16) 
years when the dependent variable is $D A(A Q)$. These results suggest that the time trend in IRS audit rates is unlikely to explain our findings.

\section{Conclusion}

In this paper, we examine the relation between tax enforcement and financial reporting quality. Our results suggest that tax authority enforcement is associated with financial reporting quality. We also find that tax enforcement has a more prominent effect on financial reporting quality when other monitoring mechanisms are weaker. Our paper contributes to the literature arguing that tax enforcement serves as a corporate governance mechanism. Desai et al. (2007) put forth a theory of the game between the state, insiders, and outside shareholders and argue that stricter tax enforcement makes it harder for insiders to extract private benefits, and hence, active monitoring by tax authorities protects the interests of outside shareholders. Empirical tests of this theory have been scarce - Guedhami and Pittman (2008) and El Ghoul et al. (2011) both show greater tax enforcement is associated with lower cost of capital. We build on this literature by showing that tax enforcement is associated with the quality of financial reporting, and thus, is potentially a mechanism by which stricter tax enforcement leads to a reduction in the cost of capital.

While the theory in Desai et al. (2007) is new and intriguing, testing the theory empirically is difficult because measures of tax authority enforcement are not easily obtained. We use the TRAC data to obtain measures of IRS enforcement in the U.S., however, a concern with using the TRAC data is that the measure of IRS enforcement that is available for the longest period of time varies only by firm size and time. While we have conducted a variety of alternative tests to attempt to mitigate this concern, to the extent that we cannot control for any underlying factors that drive both IRS audit probability measures and financial reporting quality our results will be affected. However, our results using the TRAC data are supported by the use of data from Russia around the 2000 regime shift and by aggregate data. 
In sum, our results are consistent with the theory proposed by Desai et al. (2007) and suggest that indeed the tax authority provides a monitoring mechanism of insiders and their reporting choices. As a result, tax authority enforcement constitutes another institutional countrylevel feature that affects financial reporting behavior beyond the existing accounting standards (Ball, Kothari, and Robin 2000). However, we recognize that our study does not address the efficiency of tax authority monitoring relative to other institutions, such as the SEC, in monitoring or strengthening financial reporting quality. Thus, we offer no prescription on whether tax authority monitoring should be strengthened. Rather, our research supports the view that there is a positive externality to tax authority monitoring and enforcement. 


\section{References}

Accounting Today, 1996. E\&Y taps IRS deputy counsel.(Eric Solomon joins Ernst and Young L.L.P. as a partner). April 22, 1996.

Ali, A., and L. Hwang, 2000. Country-specific factors related to financial reporting and the value relevance of accounting data. Journal of Accounting Research 38, 1-21.

Armstrong, C., W. Guay and J. Weber, 2010. Role of accounting in corporate governance and contracting. Journal of Accounting and Economics 50, 179-234.

Badertscher, B., J. Phillips, M. Pincus, and S. Rego. 2009. Earnings management strategies and the trade-off between tax benefits and detection risk: To conform or not to conform?. The Accounting Review 84(1), 63-97.

Badertscher, B., N. Shroff, and H. White. 2013. Externalities of public firm presence: Evidence from private firms' investment decisions. Journal of Financial Economics 109 (3): 682-706.

Ball, R., S. Kothari and A. Robin, 2000. The effect of international institutional factors on properties of accounting earnings. Journal of Accounting and Economics 29, 1-51.

Ball, R., A. Robin and J. Wu, 2003. Incentives versus standards: Properties of accounting income in four East Asian countries. Journal of Accounting and Economics 36, 235-270.

Beron, K.J., H.V. Tauchen and A.D. Witte, 1992. The effect of audits and socioeconomic variables on compliance, in: Joel Slemrod, ed., Why People Pay Taxes (University of Michigan Press, Ann Arbor) pp. 67-89.

Blank, J.D. and D.Z. Levin, 2010. When Is Tax Enforcement Publicized? Virginia Tax Review 30.1

Bradshaw, M.T. and G.S. Miller, 2008, Will harmonizing accounting standards really harmonize accounting? Evidence from non-US firms adopting US GAAP, Journal of Accounting, Auditing and Finance 23, 233-270.

Bushee, B., 1998. The influence of institutional investors on myopic R\&D investment behavior. The Accounting Review 73, 305-333.

Bushman, R. and J. Piotroski., 2006, Financial reporting incentives for conservative accounting: the influence of legal and political institutions, Journal of Accounting and Economics 42, 107-148.

Chen, K-P and C. Chu, 2005. Internal control vs. external manipulation: A model of corporate income tax evasion. RAND Journal of Economics 36, 151-164.

Coffee Jr., J., 1999. The future as history: the prospects for global convergence in corporate governance and its implications, Northwestern Law Review 93, 641-707. 
Crocker, K. and J. Slemrod, 2005. Corporate tax evasion with agency costs. Journal of Public Economics 89: 1593-1610.

Dechow, P. and I. Dichev, 2002. The quality of accruals and earnings: The role of accrual estimation errors. The Accounting Review 77, 35-59.

Dechow, P., W. Ge, C. Larson and R. Sloan, 2011. Predicting Material Accounting Misstatements. Contemporary Accounting Research. 28:1, 17-82.

Dechow, P., W. Ge and C. Schrand, 2010. Understanding earnings quality: A review of the proxies, their determinants and their consequences. Journal of Accounting and Economics $50,344-401$.

Dechow, P., R. Sloan and A. Sweeney, 1995. Detecting earnings management. The Accounting Review 70, 193-225.

Desai, M. 2005. The degradation of reported corporate profits. Journal of Economic Perspectives 171-192.

Desai, M. and D. Dharmapala, 2006. Corporate tax avoidance and high-powered incentives. Journal of Financial Economics 79, 145-179.

Desai, M., I, Dyck and L, Zingales, 2007. Theft and taxes. Journal of Financial Economics 84, 591-623.

Desai, M., and D. Dharmapala. 2009. Earnings management, corporate tax shelters, and book-tax alignment. National Tax Journal, 169-186.

Doyle, J., W. Ge and S. McVay, 2007. Accruals quality and internal control over financial reporting, The Accounting Review 82, pp. 1141-1170.

Dyck, I. and L. Zingales, 2004. Private benefits of control: an international comparison. Journal of Finance 59, 537-600.

Dyreng, S., M. Hanlon, and E. L. Maydew. 2012. Where do firms manage earnings? Review of Accounting Studies 17 (3): 649-87.

Dyreng, S., W. Mayew, and C. Willams, 2012. Religious Social Norms and Corporate Financial Reporting. Journal of Business Finance \& Accounting 39:7-8. 845-875.

El Ghoul, S., O. Guedhami and J. Pittman, 2011. The Role of IRS Monitoring in Equity Pricing in Public Firms. Contemporary Accounting Research, Vol. 28, pp. 643-674. 
Erickson, M., M. Hanlon and E. Maydew. 2004. How much will firms pay for earnings that do not exist? Evidence of taxes paid on allegedly fraudulent earnings. The Accounting Review 79: $387-408$.

Ewert, R. and A. Wagenhofer, 2010, Earnings quality metrics and what they measure, Working paper, University of Graz.

Fama, E. F. and K. R. French, 1997, Industry Costs of Equity. Journal of Financial Economics 43: 153-93.

Fama, E. F. and K. R. French, 2004, New lists: fundamentals and survival rates. Journal of Financial Economics 72: 229-269.

Francis, J., R. LaFond, P, Olsson, and K. Schipper, 2005. The market pricing of accruals quality. Journal of Accounting and Economics 39, 295-327.

Gleason, C. A. and L.F. Mills, 2002. Materiality and contingent tax liability reporting. The Accounting Review 77: 317-342.

Graham, J., M. Hanlon, T. Shevlin and N. Shroff. 2014. Incentives for tax planning and avoidance: Evidence from the field. The Accounting Review. In Press.

Greene W., 2003. Econometric Analysis. Englewood Cliffs, NJ: Prentice-Hall.

Guedhami, O. and J. Pittman, 2008. The importance of IRS monitoring to debt pricing in private firms. Journal of Financial Economics 90, 38-58.

Guenther, D., 1994. Earnings management in response to corporate tax rate changes: Evidence from the 1986 tax reform act. The Accounting Review 69, 230-243.

Hail, L. and C. Leuz, 2009. Cost of capital effects and changes in growth expectations around U.S. cross-listings. Journal of Financial Economics 93:3. 428-454.

Hanlon, M. and S. Heitzman, 2010. A review of tax research. Journal of Accounting and Economics 50, 127-178.

Hanlon, M., E. Maydew and T. Shevlin, 2008, An unintended consequence of book-tax conformity: a loss of earnings informativeness. Journal of Accounting and Economics, 46, 294-311.

Holthausen, R, 2009. Accounting standards, financial reporting outcomes, and enforcement. Journal of Accounting Research 47: 447-458.

Hoopes, J.L., D. Mescall and J. Pittman, 2012. Do IRS Audits Deter Corporate Tax Avoidance? The Accounting Review 87:5, 1603-1639. 
Hribar, P. and D. C. Nichols, 2007. The use of unsigned earnings quality measures in tests of earnings management. Journal of Accounting Research 45, 1017-1053.

Internal Revenue Service, 2008. Internal Revenue Service Data Book, 2008. Washington, DC: Internal Revenue Service.

Jensen, M. and W, Meckling, 1976. Theory of the firm: managerial behavior, agency costs and ownership structure. Journal of Financial Economics 3, 305-360.

Jones, J., 1991. Earnings management during import relief investigations. Journal of Accounting Research 29, 193-228.

Kang, Q., Q. Liu and R. Qi, 2010. Predicting Stock Market Returns with Aggregate Discretionary Accruals. Journal of Accounting Research 48 (4): 815-858.

Kedia, S. and S. Rajgopal, 2011. Do the SEC's enforcement preferences affect corporate misconduct? Journal of Accounting and Economics 51, 259-278.

Lang, M., J. Raedy and W. Wilson, 2006. Earnings management and cross listing: Are reconciled earnings comparable to us earnings?. Journal of Accounting and Economics 42, 255-283.

Larsen, R.G., R.D. Beran, R. D'Avino, and W.D. Hawkins, 2007. Session 5: Developing a Global Corporate Tax Risk Strategy. Taxes - The Tax Magazine (June): 83-94.

Leuz, C. and D. Nanda and P. Wysocki, 2003. Earnings management and investor protection: An international comparison. Journal of Financial Economics 69, 505-527.

Leuz, C., 2003. IAS versus US GAAP: Information Asymmetry-Based Evidence from Germany's New Market. Journal of Accounting Research 41: 445-72.

Maydew, E., 1997. Tax-induced earnings management by firms with net operating losses. Journal of Accounting Research 35 (1), 83-96.

McNichols, M. F. 2002. Discussion of the Quality of Accruals and Earnings: The Role of Accrual Estimation Errors. The Accounting Review 77 (Supplement 2002): 61-69.

Mills, L. 1998. Book-tax differences and Internal Revenue Service adjustments. Journal of Accounting Research, 343-356.

Noreen, E., 1989, Computer-Intensive Methods for Testing Hypotheses: An Introduction (John Wiley and Sons, New York).

Novack, J. and L. Saunders, (1998, December 14). The Hustling of X-Rated Tax Shelters. Forbes, 198. 
Phillips, J., M. Pincus and S. Rego, 2003. Earnings management: New evidence based on deferred tax expense. The Accounting Review 78, 491-521.

PricewaterhouseCoopers. (2006, August 24). PricewaterhouseCoopers LLP Names John Petrella Managing Director in the Firm's Washington National Tax Services Practice. GlobeNewswire

Schneider, C., (2005, July 29). IRS to Audit More S Corporations. CFO.com

Scholes, M., P. Wilson and M. Wolfson, 1992. Firms' responses to anticipated reductions in tax rates: the Tax Reform Act of 1986. Journal of Accounting Research 30 (Suppl.), 161-191.

Shackelford, D., and T. Shevlin. 2001. Empirical tax research in accounting. Journal of Accounting and Economics 31:321-387.

Shleifer, A., and R. Vishny. 1997. A survey of corporate governance. The Journal of Finance 52(2), 737-783.

Shroff, N., Verdi, R., Yu, G., 2014. Information environment and the investment decisions of multinational corporations. The Accounting Review 89, 759-790.

Skinner, D. 2008, The evolving relation between earnings, dividends, and stock repurchases. Journal of Financial Economics 87, 582-609.

Slemrod, J. and Yitzahaki, S., 2002. Tax Avoidance, Evasion, and Administration. In A. Auerbach, M. Feldstein Eds., Handbook of Public Economics pp. 1423-1470. Elsevier Science.

Stulz, R., 1999. Globalization, Corporate Finance, and the Cost of Capital. Journal of Applied Corporate Finance 12:8-25.

Transactional Records Access Clearinghouse. 2005. IRS History. Retrieved July 10, 2009, from Transactional Records Access Clearinghouse: http://trac.syr.edu/tracirs/atwork/current/irsHistory.html 


\section{Appendix A \\ Description of Proxies for IRS Monitoring}

Our measures of IRS enforcement are obtained from the Transactional Records Access Clearinghouse (TRAC) based out of Syracuse University. TRAC is a non-profit entity founded in 1989 which obtains information directly from the IRS. In recent years, the IRS has disclosed these data to the public in their annual Data Book, available on the IRS's website. The data used to construct the audit probability measures originate from the IRS's Audit Management Information Reporting System (AIMS), the system that is used to generate reports given to Congress, the public, and for internal use (see Guedhami and Pittman 2008).

Audit probability is defined as the number of corporate tax return audits completed in the IRS fiscal year t (October 1 to September 30), divided by the number of corporate tax returns received in calendar year $\mathrm{t}-1$. One concern about this measure is the imperfect link between the number of tax returns in the numerator and the denominator. To proxy for the total pool of returns filed and available to audit in the current IRS fiscal year, the IRS uses the number of tax returns received in the previous calendar year. Therefore, the measure implicitly assumes that returns take about one year to audit. ${ }^{30}$ While the IRS asserts that on average this is a good estimate, Gleason and Mills (2002) suggest that on average, the very largest corporate filers take about three years to audit. To the extent the above assumption is violated, the audit probability measure is a noisy proxy for the level of tax enforcement. Despite the limitation of the measure, this is the statistic that the IRS uses internally, that it reports to Congress, that it is under court order to disclose to the public on a monthly basis, and is the only statistic on audit coverage that is available publicly.

Audit coverage data is available from TRAC on a firm size and year basis for the time period 1992-2008 and, on a firm size, time, and IRS district basis for the period 1992-2000.

\footnotetext{
${ }^{30}$ In their 2008 Data Book, the IRS justifies their assumption that returns take one year to audit by asserting that "In general, examination activity is associated with returns filed in the previous calendar year (Internal Revenue Service, 2008)."
} 
Thus, our first IRS audit coverage measure, Size/Time Audit Probability, takes advantage of the temporal and size induced variation in IRS audit coverage for the 17 years for which TRAC maintains data. Our other two measures, District/Size/Time Audit Probability and District/Time Audit Probability, take advantage of temporal and cross-sectional variation (geographic and size) in the 1992-2000 periods. The first, District/Size/Time Audit Probability, is the number of audits completed in IRS fiscal year $\mathrm{t}$ in a given IRS district for a given IRS asset class group, divided by the number of returns received in that same district and IRS asset size group in IRS calendar year $\mathrm{t}-1$. The second measure, District/Time Audit Probability, is the number of audits completed in IRS fiscal year $\mathrm{t}$ in a given IRS district, divided by the number of returns received in that same district in IRS calendar year t-1, making District/Time Audit Probability mechanically unrelated to firm size.

For our dependent variables which vary with geographic region (District/Size/Time Audit Probability and District/Time Audit Probability), we assign firms to an IRS district based on their Compustat state (i.e., location of corporate headquarters). Most IRS districts are comprised of a single state. However, there are some states such as California, Florida, Texas, and New York that contain more than one IRS district within the state and some states which share an IRS district. When a state is divided into multiple districts, we use the average audit probability across IRS districts in that state and assign each state a single audit probability. When multiple states share an IRS district, all states sharing the district are assigned the same audit probability.

There is one important caveat of the above geographic based measure. IRS auditors from any given district could potentially audit any firm in the U.S. For example, when auditing a return, if there are related corporations, major clients, or suppliers that appear like attractive audit candidates, IRS auditors can audit that entity, regardless of its geographical location. However, while a firm may be audited by IRS auditors from any district, it is much more likely that a firm is audited by the district in which its headquarters are located. Therefore, firms are likely to consider IRS enforcement in the district in which they reside. 
One last feature of our measure of Audit Probability is that the very largest corporations in the U.S. effectively get audited by the IRS every year as a result of being classified by the IRS as Coordinated Industry Case (CIC) firms. Since these firms in effect have an audit probability that approaches 1, we re-set the values of all three measures of Audit Probability to 1 for the firms likely to be in the CIC program in our analyses. Membership in the CIC is confidential information and only access to IRS records will reveal exactly which firms are audited every year. ${ }^{31}$ Gleason and Mills (2002) indicate that there are about 1,000 CIC firms every year. Therefore we identify the 1,000 largest firms by assets each year and classify them as part of the CIC program. ${ }^{32}$

\footnotetext{
${ }^{31}$ Also note that firms do not disclose this information-brief searches of 10-Ks reveal that fewer than five firms in the 1992-2008 period disclose that they are a CIC firm.

${ }^{32}$ In untabulated tests, we identify 1,000 firms each year most likely to be part of the CIC program using a procedure based on IRM Exhibit 4.46.2-2. Using this alternative methodology to identify CIC firms does not affect our inferences.
} 
Appendix B

Variable Definitions

\begin{tabular}{|c|c|}
\hline Variable & Definition \\
\hline Accruals Quality & 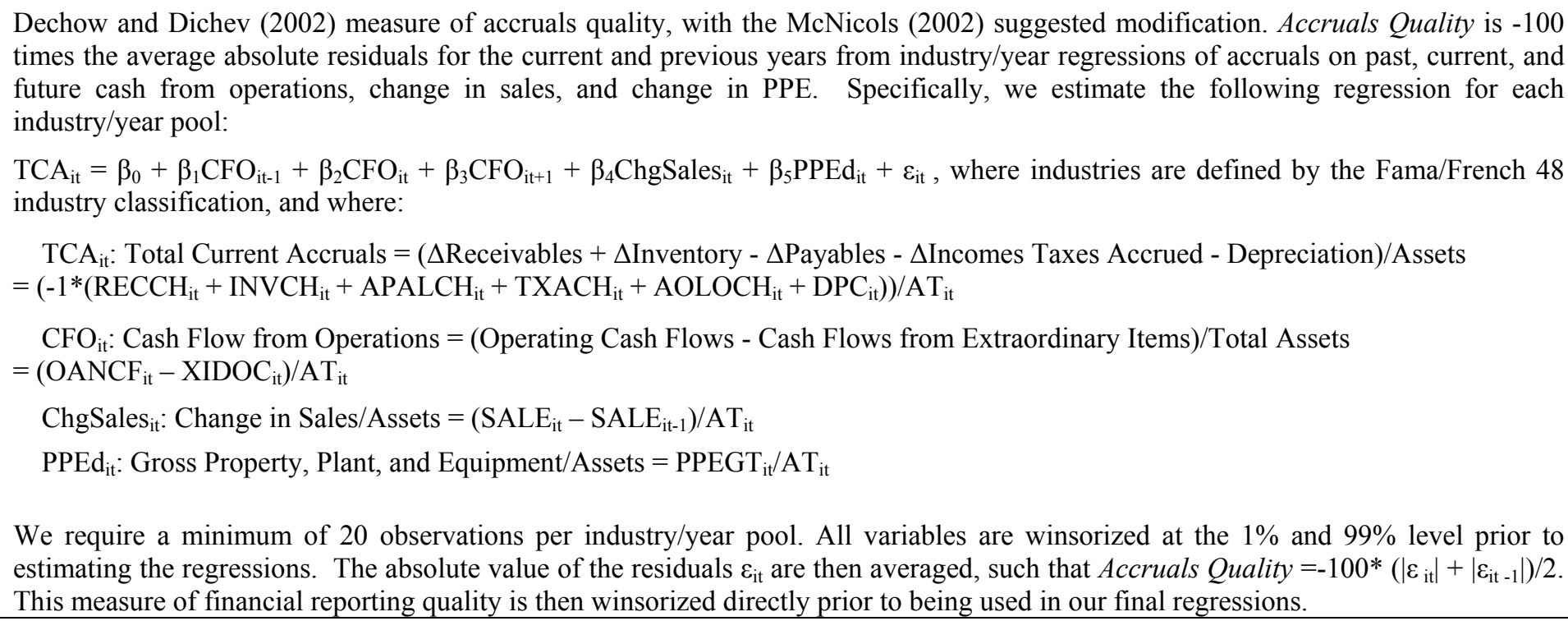 \\
\hline $\begin{array}{l}\text { Discretionary } \\
\text { Accruals }\end{array}$ & 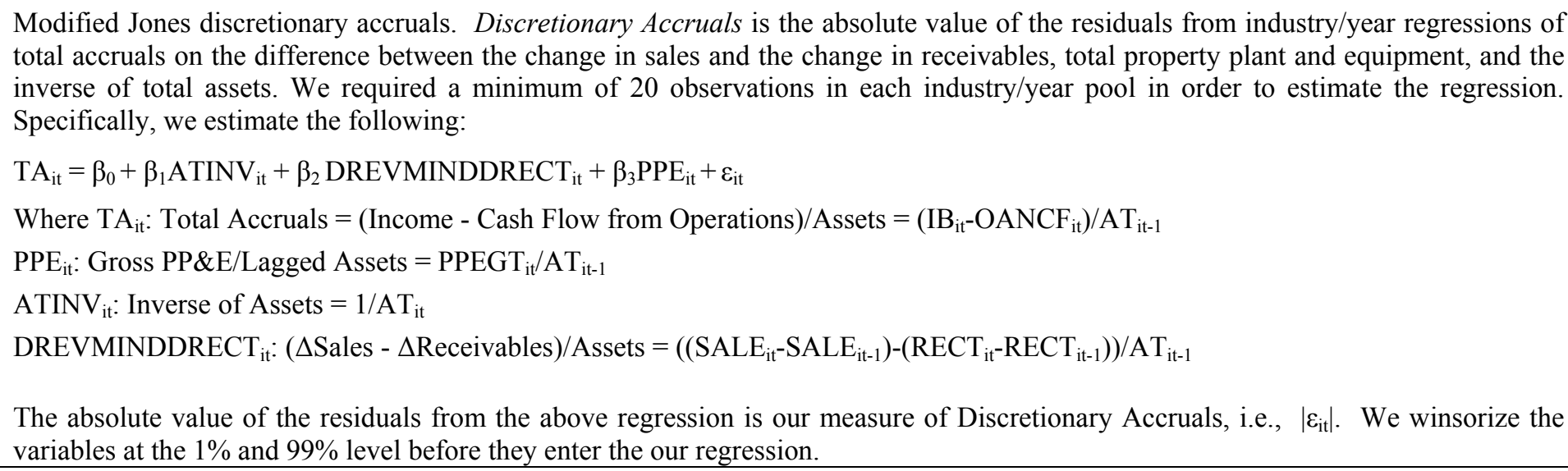 \\
\hline Dedicated Investors & $\begin{array}{l}\text { The percentage of the firm's equity held by dedicated institutional investors in year } t \text {. Calculated from data provided in the Thomson- } \\
\text { Reuter's Institutional Holdings (13F) Database, where dedicated institutional investors are defined as in Bushee (1998). We set the } \\
\text { variable to } 0 \text { if the data are missing. }\end{array}$ \\
\hline
\end{tabular}


Size/Time Audit Probability Audit Probability

District/Time Audit Probability

Assets

Leverage

ROA

$\ln$ (MVE)

Market to Book

SD Cash Flows

SD Sales

Operating Cycle

Capital Intensity

Intangibles Intensity

Presence of

Intangibles

Negative Earnings

Institutional

Investors
The number of returns whose audit was completed in IRS fiscal year $t$ in IRS asset size $s$ divided by the number of returns that were filed in IRS calendar year $t-1$ in IRS asset size $s$. This is adjusted for Coordinated Industry Case firms, so that the audit probability for the 1000 largest firms (by assets) in each year is set equal to 1 .

The number of returns whose audit was completed in IRS fiscal year $t$ in IRS asset size $s$ in IRS district $d$ divided by the number of returns that were filed in IRS calendar year $t-1$ in IRS asset size $s$ in IRS district $d$. This is adjusted for Coordinated Industry Case firms, so that the audit probability for the 1000 largest firms (by assets) in each year is set equal to 1 . We assign firms to districts based upon the state variable in Compustat, which is most commonly the state in which they are physically headquartered. It is important to note that this is not the state of incorporation, which would yield little variation since a large portion of public firms are incorporated in Delaware. Only $0.46 \%$ of our sample is headquartered in Delaware.

The number of returns whose audit was completed in IRS fiscal year $t$ in IRS district $d$ divided by the number of returns that were filed in IRS calendar year $t-1$ in IRS district $d$. This is adjusted for Coordinated Industry Case firms, so that the audit probability for the 1000 largest firms (by assets) in each year is set equal to 1. We assign firms to districts based upon the state variable in Compustat, which is most commonly the state in which they are physically headquartered.

Total Assets $=\mathrm{AT}_{\mathrm{it}}$

Leverage: Long term debt/Lagged Assets $=\mathrm{DLTT}_{\mathrm{it}} / \mathrm{AT}_{\mathrm{it}-1}$

Return on Assets: $\mathrm{ROA}_{\mathrm{it}}=$ Income before extra-ordinary items/Assets $=\mathrm{IB}_{\mathrm{it}} / \mathrm{AT}_{\mathrm{it}}$

Log of Market Value of Equity $=\ln \left(\mathrm{PRCC}_{-} \mathrm{F}_{\mathrm{it}}{ }^{*} \mathrm{CSHO}_{\mathrm{it}}\right)$

Market to Book: (Market Value of Equity + Book Value Debt) $/$ Book Value of Assets $\left.=\left|\left(\mathrm{PRCC}_{-} \mathrm{F}_{\mathrm{it}} * \mathrm{CSHO}_{\mathrm{it}}\right)\right|+\mathrm{DLTT}_{\mathrm{it}}+\mathrm{DLC}_{\mathrm{it}}\right) / \mathrm{AT}_{\mathrm{it}}$

The standard deviation of the 10 prior year's cash from operations (OANCF) scaled by assets in the current period (AT $)$.

The standard deviation of the ten prior year's sales (SALE) scaled by total assets (AT).

The natural $\log$ of the operating cycle of the firm: $\ln$ (Days Sales+Days Inventory) $=\ln [(360 /($ SALEit/(RECTit + RECTit1)/2) $)+(360 /($ COGSit/(INVTit+INVTit-1)/2)]

The net value of property plant and equipment scaled by lagged total assets $=\mathrm{PPENT}_{\mathrm{it}} / \mathrm{AT}_{\mathrm{it}-1}$

The sum of research and development spending and advertising expense scaled by sales $=\left(\mathrm{XRD}_{\mathrm{it}}+\mathrm{XAD}_{\mathrm{it}}\right) / \mathrm{SALE}_{\mathrm{it}}$. If either $\mathrm{xrd}$ or $\mathrm{xad}$ is missing, it is presumed to be zero.

A dummy variable coded 1 if the firm has zero spending in both research and development and advertising. Specifically, if Intangible Intensity is 0 , then Presence of Intangibles $=1$, otherwise, Presence of Intangibles $=0$ ).

The proportion of loss years in the prior 10 years. Specifically, if $\mathrm{NI}_{\mathrm{it}}<0$ then the firm had a loss year in year $t$. Negative earnings is defined as the total number of loss years the firm experienced in the previous 10 years divided the total number of years for which net income data is available that firm in the previous 10 years.

The percentage of the firm's equity held by institutional investors in year $t$. Calculated using data provided in the Thomson-Reuter's Institutional Holdings (13F) Database. Set equal to 0 if the data is missing. 
FIGURE 1

Time Trend in Audit Rates and Financial Reporting Quality Proxies by Asset Size Group

\section{Panel A: Audit Rates}

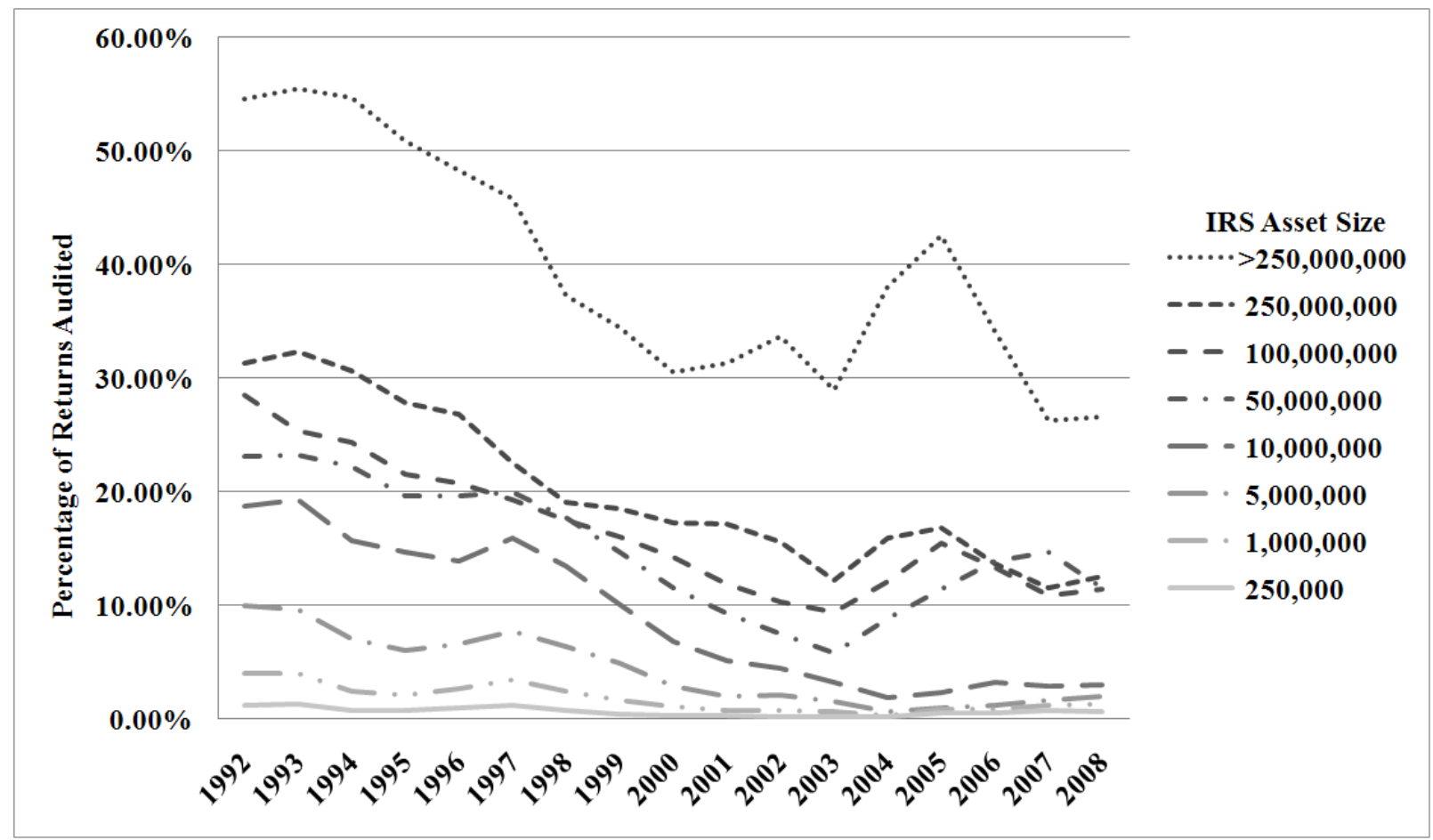


Panel B: Discretionary Accruals

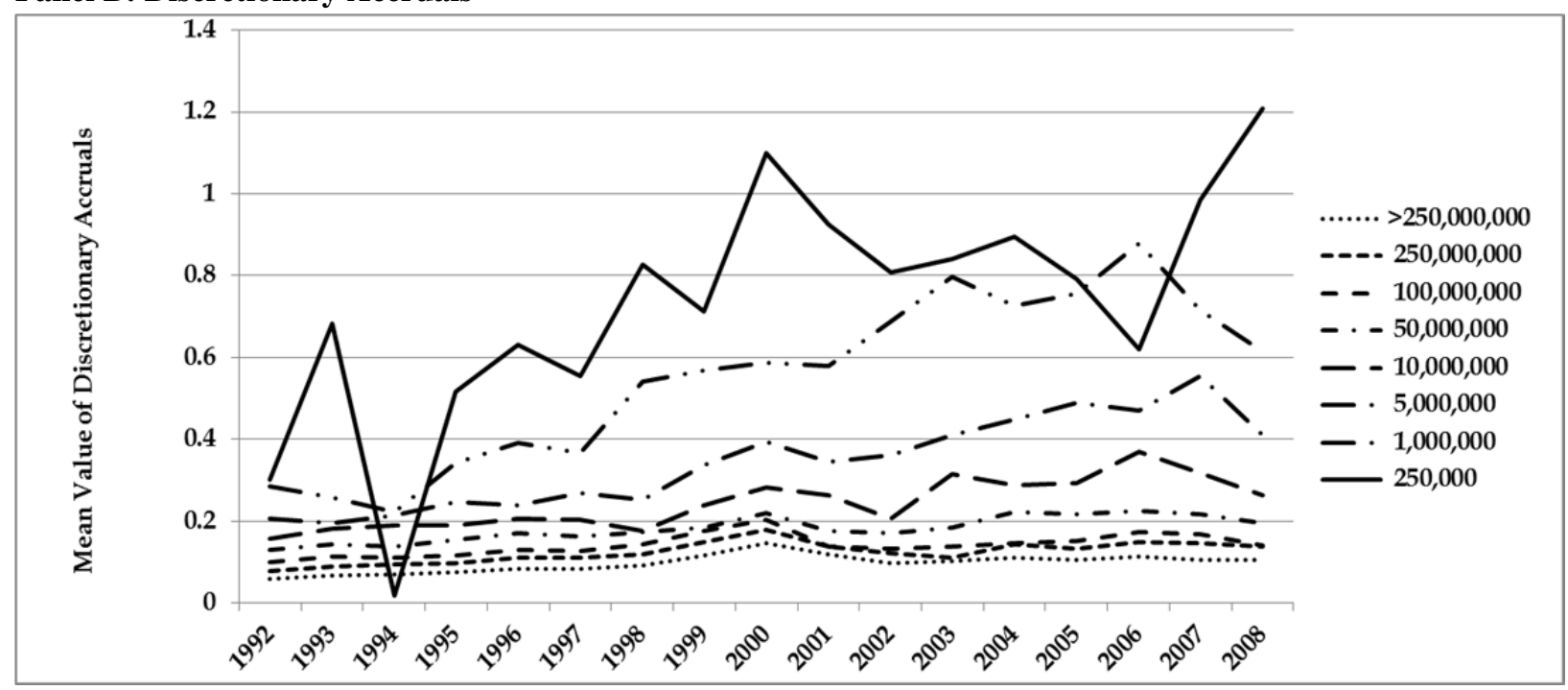

Panel C: Accrual Quality

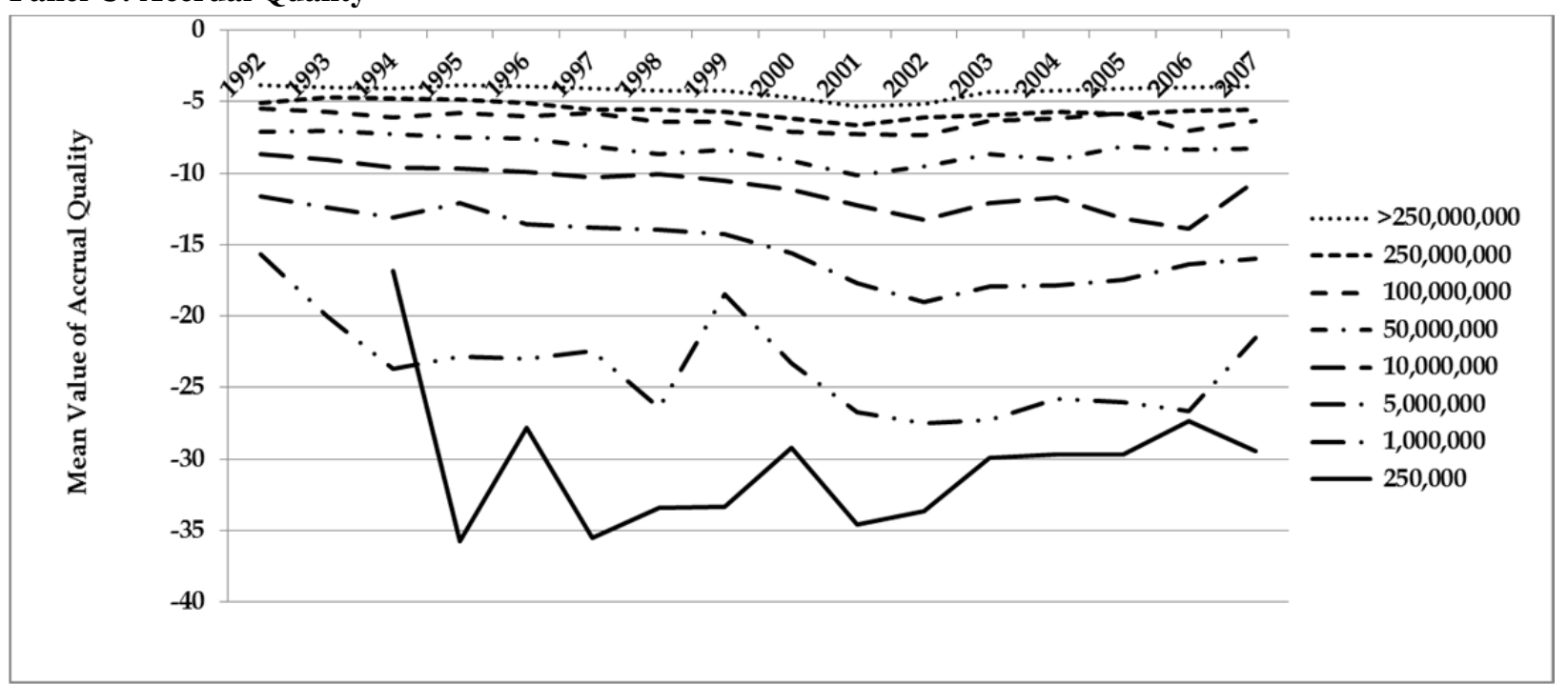

Notes: These graphs present the time trend in audit probability (Panel A) and our measures of financial reporting quality (Panels B and C) for firms in specific IRS asset-size groups using data obtained from the Transactional Records Access Clearinghouse. In Panel A, each line represents the proportion of corporate tax audits completed in the given IRS fiscal year $t$ for that asset class, divided by the number of corporate tax returns in IRS calendar year $t$ 1 for that asset class. In Panel B (C), each line represents the average discretionary accruals (accrual quality) of the firms within the asset-size group. The $\mathrm{x}$-axis in all three panels represents calendar years. 
TABLE 1

Sample Selection

\begin{tabular}{lc}
\hline Sample Selection & $\begin{array}{l}\text { Firm-Year } \\
\text { Observations }\end{array}$ \\
\hline \hline All Compustat Firms between 1992 and 2008 & 196,485 \\
Firms with data on assets & 172,269 \\
Firms Incorporated in the US & 142,491 \\
Firms located in a US State & 139,872 \\
Corporations & 137,016 \\
Non-financial firms or Utilities & 110,663 \\
Not enough data to calculate all control variables & 65,416 \\
& \\
Dechow Dichev Earnings Quality measure & 46,338 \\
Modified Jones Discretionary Accruals & 64,982 \\
\hline \hline
\end{tabular}

Notes: Firms Incorporated in the U.S. are Firms with FIC = "USA." Firms located in a US State are all firms where state is not equal to any of the following: "AB," "BC," "NF," "ON," "PR," "QC," "SK," "VI," "NS." Corporations are firms which meet the following conditions: 1) The firm does not have "TRUST," "LP," "LP" or "L P" in its name, 2) Its six digit CUSIP does not end in "Y" or "Z," and its SIC code is not 6798. Non-financial firms or Utilities are firms whose SIC codes are not between 6000 and 7000 or between 4900 and 5000. 
TABLE 2

Descriptive Statistics and Correlations

Panel A: Descriptive Statistics

\begin{tabular}{|c|c|c|c|c|c|c|c|c|}
\hline Variable & Mean & STD & Min & P25 & P50 & P75 & $\operatorname{Max}$ & $\mathbf{N}$ \\
\hline \multicolumn{9}{|l|}{$\begin{array}{l}\text { Measures of Financial Reporting } \\
\text { Quality }\end{array}$} \\
\hline Discretionary Accruals & 0.15 & 0.21 & 0.00 & 0.04 & 0.09 & 0.18 & 1.42 & 64,982 \\
\hline Accruals Quality & -6.95 & 7.09 & -42.45 & -8.47 & -4.75 & -2.63 & -0.43 & 46,338 \\
\hline \multicolumn{9}{|l|}{ Measures of Audit Probability } \\
\hline Size/Time Audit Probability & 0.40 & 0.37 & 0.00 & 0.14 & 0.22 & 1.00 & 1.00 & 64,982 \\
\hline District/Size/Time Audit Probability & 0.40 & 0.35 & 0.00 & 0.16 & 0.24 & 0.57 & 1.00 & 38,653 \\
\hline District/Time Audit Probability & 0.25 & 0.41 & 0.01 & 0.02 & 0.02 & 0.04 & 1.00 & 38,653 \\
\hline \multicolumn{9}{|l|}{ Control Variables } \\
\hline Assets (in Millions) & 1,215 & 3,838 & 1 & 24 & 109 & 561 & 27,732 & 64,982 \\
\hline Ln (MVE) & 4.70 & 2.34 & -0.67 & 3.03 & 4.63 & 6.31 & 10.44 & 64,982 \\
\hline SD Cash Flows & 0.12 & 0.21 & 0.01 & 0.03 & 0.06 & 0.10 & 1.56 & 64,982 \\
\hline Market to Book & 1.93 & 2.27 & 0.25 & 0.81 & 1.22 & 2.08 & 15.72 & 64,982 \\
\hline Return on Assets & -0.12 & 0.48 & -3.18 & -0.09 & 0.02 & 0.07 & 0.27 & 64,982 \\
\hline Leverage & 0.21 & 0.29 & 0.00 & 0.00 & 0.12 & 0.31 & 1.69 & 64,982 \\
\hline SD Sales & 0.42 & 0.56 & 0.02 & 0.16 & 0.27 & 0.46 & 4.16 & 64,982 \\
\hline Operating Cycle & 4.76 & 0.77 & 2.20 & 4.38 & 4.82 & 5.21 & 6.93 & 64,982 \\
\hline Capital Intensity & 0.31 & 0.28 & 0.01 & 0.11 & 0.23 & 0.42 & 1.52 & 64,982 \\
\hline Intangible Intensity & 0.15 & 0.53 & 0.00 & 0.00 & 0.02 & 0.09 & 4.28 & 64,982 \\
\hline Presence of Intangibles & 0.32 & 0.47 & 0.00 & 0.00 & 0.00 & 1.00 & 1.00 & 64,982 \\
\hline Negative Earnings & 0.37 & 0.34 & 0.00 & 0.00 & 0.30 & 0.60 & 1.00 & 64,982 \\
\hline Institutional Investors & 0.29 & 0.31 & 0.00 & 0.00 & 0.17 & 0.53 & 1.00 & 64,982 \\
\hline Dedicated Investors & 0.05 & 0.07 & 0.00 & 0.00 & 0.00 & 0.07 & 1.00 & 64,982 \\
\hline
\end{tabular}

Notes: Panel A reports descriptives statistics for the firms in our dataset. Accruals Quality is the Dechow and Dichev (2002) measure of accruals quality with the modification suggested by McNichols (2002). It is the average absolute value of the past two year's residuals (multiplied by -100) from industry/year regressions of accruals on past, current, and future cash from operations, change in sales, and change in property, plant and equipment. Discretionary Accruals are the absolute value of the residuals from industry/year regressions of accruals on the difference between the change in sales and the change in receivables, and total property plant and equipment (Jones 1991; Dechow et al. 1995). Size/Time Audit Probability is the number of tax returns audited in IRS fiscal year $\mathrm{t}$ divided by the number of returns filed in IRS calendar year t-1, adjusted for CIC firms. District/Size/Time Audit Probability is the number of tax returns audited in IRS fiscal year $\mathrm{t}$, asset size s, and district d divided by the number of returns that were filed in calendar year t-1 in that group, adjusted for CIC firms. District/Time Audit Probability is the number of tax returns audited in IRS fiscal year $t$ and IRS district d divided by the number of returns filed in calendar year t-1 in that group, adjusted for CIC firms. Assets is the total assets of the firm. $L n(M V E)$ is the natural $\log$ of market value of equity on the fiscal end date. SD Cash Flows is the standard deviation of the prior 10 years cash from operations scaled by total assets. Market to Book is the firm's market value of asset divided by the book value of assets. Return on Assets is the firm's income before extraordinary items scaled by total assets. Leverage is the firm's total long term debt scaled by lagged assets. SD Sales is the standard deviation of the prior 10 years sales scaled by total assets in the current period. Operating Cycle is the natural log of Days Sales + Days Inventory. Capital Intensity is the net value of property plant and equipment scaled by total assets in the prior period. Intangible Intensity is the sum of research and development spending and advertising scaled by total sales. Presence of Intangibles is a dummy variable coded 1 if research and development and advertising spending is equal to 0. Negative Earnings is the proportion of losses of the prior 10 years. Institutional Investors is the percentage of the firm's equity held by institutional investors in year t. Dedicated Investors is the percentage of the firm's equity held by dedicated institutional investors (as defined in Bushee 1998) in year t. 
TABLE 2 - continued

Panel B: Correlation Matrix

\begin{tabular}{|c|c|c|c|c|c|c|c|c|c|c|c|c|c|c|c|c|c|c|c|c|}
\hline & & 1 & 2 & 3 & 4 & 5 & 6 & 7 & 8 & 9 & 10 & 11 & 12 & 13 & 14 & 15 & 16 & 17 & 18 & 19 \\
\hline 1 & Discretionary Accruals & & -0.40 & -0.29 & -0.26 & -0.20 & -0.27 & -0.20 & 0.27 & 0.14 & -0.17 & -0.09 & 0.11 & 0.05 & -0.11 & 0.11 & -0.03 & 0.24 & -0.19 & -0.18 \\
\hline 2 & Accruals Quality & -0.47 & & 0.38 & 0.35 & 0.23 & 0.41 & 0.34 & -0.48 & -0.10 & 0.28 & 0.17 & -0.25 & -0.12 & 0.25 & -0.15 & 0.06 & -0.36 & 0.28 & 0.25 \\
\hline 3 & Size/Time Audit Probability & -0.23 & 0.31 & & 0.90 & 0.68 & 0.86 & 0.76 & -0.52 & -0.05 & 0.30 & 0.32 & -0.22 & -0.14 & 0.29 & -0.16 & 0.05 & -0.44 & 0.46 & 0.44 \\
\hline 4 & $\begin{array}{l}\text { District/Size/Time Audit } \\
\text { Probability }\end{array}$ & -0.21 & 0.30 & 0.98 & & 0.67 & 0.83 & 0.72 & -0.49 & -0.07 & 0.28 & 0.31 & -0.21 & -0.14 & 0.27 & -0.16 & 0.05 & -0.40 & 0.43 & 0.41 \\
\hline 5 & District/Time Audit Probability & -0.17 & 0.24 & 0.97 & 0.95 & & 0.51 & 0.48 & -0.29 & 0.03 & 0.15 & 0.18 & -0.13 & -0.08 & 0.17 & -0.05 & -0.01 & -0.23 & 0.24 & 0.25 \\
\hline 6 & Assets & -0.09 & 0.14 & 0.48 & 0.45 & 0.47 & & 0.87 & -0.59 & -0.08 & 0.32 & 0.34 & -0.25 & -0.17 & 0.31 & -0.16 & 0.05 & -0.48 & 0.54 & 0.51 \\
\hline 7 & ln MVE & -0.22 & 0.36 & 0.75 & 0.74 & 0.67 & 0.53 & & -0.48 & 0.35 & 0.41 & 0.15 & -0.27 & -0.12 & 0.25 & 0.03 & -0.07 & -0.44 & 0.55 & 0.52 \\
\hline 8 & SD Cash Flows & 0.36 & -0.56 & -0.30 & -0.29 & -0.20 & -0.12 & -0.37 & & 0.11 & -0.30 & -0.33 & 0.33 & 0.15 & -0.36 & 0.23 & -0.10 & 0.47 & -0.34 & -0.31 \\
\hline 9 & Market to Book & 0.32 & -0.30 & -0.16 & -0.14 & -0.10 & -0.06 & 0.07 & 0.41 & & 0.19 & -0.17 & -0.05 & 0.04 & -0.03 & 0.33 & -0.19 & 0.05 & 0.07 & 0.05 \\
\hline 10 & Return on Assets & -0.45 & 0.51 & 0.27 & 0.25 & 0.17 & 0.10 & 0.34 & -0.69 & -0.43 & & -0.07 & -0.02 & -0.12 & 0.15 & -0.15 & 0.02 & -0.61 & 0.34 & 0.30 \\
\hline 11 & Leverage & 0.09 & 0.01 & 0.20 & 0.22 & 0.19 & 0.06 & 0.07 & -0.05 & -0.02 & -0.01 & & -0.11 & -0.15 & 0.40 & -0.30 & 0.19 & -0.05 & 0.06 & 0.06 \\
\hline 12 & SD Sales & 0.19 & -0.38 & -0.21 & -0.19 & -0.15 & -0.11 & -0.33 & 0.58 & 0.14 & -0.31 & -0.06 & & -0.18 & -0.23 & -0.15 & 0.11 & 0.07 & -0.16 & -0.15 \\
\hline 13 & Operating Cycle & 0.03 & -0.09 & -0.13 & -0.12 & -0.10 & -0.06 & -0.09 & 0.11 & 0.08 & -0.12 & -0.14 & -0.07 & & -0.40 & 0.37 & -0.30 & 0.09 & -0.03 & -0.04 \\
\hline 14 & Capital Intensity & 0.07 & 0.14 & 0.18 & 0.19 & 0.17 & 0.09 & 0.15 & -0.18 & -0.05 & 0.13 & 0.37 & -0.18 & -0.40 & & -0.27 & 0.17 & -0.19 & 0.14 & 0.13 \\
\hline 15 & Intangible Intensity & 0.16 & -0.16 & -0.15 & -0.14 & -0.11 & -0.06 & -0.06 & 0.26 & 0.29 & -0.39 & -0.05 & -0.03 & 0.18 & -0.11 & & -0.84 & 0.23 & -0.01 & -0.01 \\
\hline 16 & Presence of Intangibles & -0.02 & 0.04 & 0.04 & 0.04 & 0.02 & -0.04 & -0.08 & -0.05 & -0.13 & 0.07 & 0.15 & 0.08 & -0.23 & 0.24 & -0.19 & & -0.10 & -0.04 & -0.02 \\
\hline 17 & Negative Earnings & 0.31 & -0.40 & -0.39 & -0.35 & -0.26 & -0.19 & -0.42 & 0.41 & 0.28 & -0.51 & 0.04 & 0.17 & 0.08 & -0.11 & 0.35 & -0.10 & & -0.40 & -0.36 \\
\hline 18 & Institutional Investors & -0.21 & 0.29 & 0.51 & 0.45 & 0.39 & 0.25 & 0.63 & -0.26 & -0.07 & 0.26 & 0.01 & -0.20 & -0.05 & 0.03 & -0.09 & -0.06 & -0.37 & & 0.83 \\
\hline 19 & Dedicated Investors & -0.15 & 0.19 & 0.32 & 0.28 & 0.24 & 0.15 & 0.39 & -0.17 & -0.08 & 0.17 & 0.02 & -0.13 & -0.04 & 0.03 & -0.07 & -0.02 & -0.24 & 0.66 & \\
\hline
\end{tabular}

Notes: Panel B reports pair wise Spearman (Pearson) correlation coefficients above (below) the diagonal for the firms in our dataset. All correlation coefficients are significant at the two tailed 5\% level. Accruals Quality is the Dechow and Dichev (2002) measure of accruals quality with the modification suggested by McNichols (2002) and equals the average absolute value of the past two year's residuals (multiplied by -100) from industry/year regressions of accruals on past, current, and future cash from operations, change in sales and change in property, plant and equipment. Discretionary Accruals is the absolute value of the residuals from industry/year regressions of accruals on the difference between the change in sales and the change in receivables, and total property plant and equipment (Jones 1991 ; Dechow et al. 1995). Size/Time Audit Probability is the number of tax returns audited in IRS fiscal year t divided by the number of returns filed in IRS calendar year t-1, adjusted for CIC firms. District/Size/Time Audit Probability is the number of tax returns audited in IRS fiscal year t, asset size s, and district d divided by the number of returns that were filed in calendar year t-1 in that group, adjusted for CIC firms. District/Time Audit Probability is the number of tax returns audited in IRS fiscal year t and IRS district d divided by the number of returns filed in calendar year t-1 in that group, adjusted for CIC firms. Assets is the total assets of the firm. Ln (MVE) is the natural log of market value of equity on the fiscal end date. SD Cash Flows is the standard deviation of the prior 10 years cash from operations scaled by total assets. Market to Book is the firm's market value of asset divided by the book value of assets. Return on Assets is the firm's income before extraordinary items scaled by total assets. Leverage is the firm's total long term debt scaled by lagged assets. SD Sales is the standard deviation of the prior 10 years sales scaled by total assets in the current period. Operating Cycle is the natural log of Days Sales + Days Inventory. Capital Intensity is the net value of property plant and equipment scaled by total assets in the prior period. Intangible Intensity is the sum of research and development spending and advertising scaled by total sales. Presence of Intangibles is a dummy variable coded 1 if research and development and advertising spending is equal to 0. Negative Earnings is the proportion of losses of the prior 10 years. Institutional Investors is the percentage of the firm's equity held by institutional investors in year t. Dedicated Investors is the percentage of the firm's equity held by dedicated institutional investors (as defined in Bushee 1998) in year t. 
TABLE 3

Regression of Financial Reporting Quality (FRQ) on Audit Probability where FRQ is Measured Using Discretionary Accruals from Jones (1991) and Dechow, Sloan, and Sweeney (1995), and the Dechow and Dichev (2002) Measure

\begin{tabular}{|c|c|c|c|c|}
\hline \multirow{2}{*}{$\begin{array}{l}\text { Dependent Variable: } \\
\text { Independent Variables }\end{array}$} & \multicolumn{3}{|c|}{ Discretionary Accruals } & \multirow{2}{*}{$\begin{array}{c}\text { Accrual Quality } \\
\text { Coefficient } \\
\text { (t-statistic) }\end{array}$} \\
\hline & $\begin{array}{c}\text { Predicted } \\
\text { Sign } \\
\end{array}$ & $\begin{array}{l}\text { Coefficient } \\
\text { (t-statistic) } \\
\end{array}$ & $\begin{array}{c}\text { Predicted } \\
\text { Sign } \\
\end{array}$ & \\
\hline Size/Time Audit Probability & - & $\begin{array}{c}-0.028 * * * \\
(-4.72)\end{array}$ & + & $\begin{array}{c}0.713 * * * \\
(3.06)\end{array}$ \\
\hline Ln MVE & & $\begin{array}{r}-0.000 \\
(-0.26)\end{array}$ & & $\begin{array}{c}0.322 * * * \\
(5.09)\end{array}$ \\
\hline Proximity $\times$ SEC Budget & & $\begin{array}{l}0.000 \\
(0.98)\end{array}$ & & $\begin{array}{l}-0.000 \\
(-1.17)\end{array}$ \\
\hline SD Cash Flows & & $\begin{array}{r}-0.015 \\
(-0.76)\end{array}$ & & $\begin{array}{c}-8.239 * * * \\
(-11.38)\end{array}$ \\
\hline Market to Book & & $\begin{array}{c}0.010^{* * *} \\
(8.67)\end{array}$ & & $\begin{array}{c}-0.177 * * * \\
(-4.85)\end{array}$ \\
\hline Return on Assets & & $\begin{array}{c}-0.095 * * * \\
(-11.74)\end{array}$ & & $\begin{array}{c}1.806 * * * \\
(7.23)\end{array}$ \\
\hline Leverage & & $\begin{array}{c}0.047 * * * \\
(6.55)\end{array}$ & & $\begin{array}{l}-0.292 \\
(-1.17)\end{array}$ \\
\hline SD Sales & & $\begin{array}{c}0.014 * * * \\
(2.76)\end{array}$ & & $\begin{array}{c}-0.859 * * * \\
(-4.06)\end{array}$ \\
\hline Operating Cycle & & $\begin{array}{c}-0.011 * * * \\
(-2.78)\end{array}$ & & $\begin{array}{c}-0.294 * * \\
(-1.97)\end{array}$ \\
\hline Capital Intensity & & $\begin{array}{c}0.254 * * * \\
(22.73)\end{array}$ & & $\begin{array}{c}-1.881 * * * \\
(-4.99)\end{array}$ \\
\hline Intangible Intensity & & $\begin{array}{l}0.003 \\
(0.56)\end{array}$ & & $\begin{array}{c}0.475^{* * *} \\
(2.94)\end{array}$ \\
\hline Presence of Intangibles & & $\begin{array}{c}0.011 * * * \\
(2.75)\end{array}$ & & $\begin{array}{l}-0.092 \\
(-0.59)\end{array}$ \\
\hline Negative Earnings & & $\begin{array}{c}0.018^{* *} \\
(2.20)\end{array}$ & & $\begin{array}{c}-1.765 * * * \\
\quad(-4.94)\end{array}$ \\
\hline Year Fixed Effects & & Yes & & Yes \\
\hline Firm Fixed Effects & & Yes & & Yes \\
\hline Standard Errors & & Clustered by firm & & Clustered by firm \\
\hline Observations & & 64,982 & & 46,338 \\
\hline R-squared & & $51.5 \%$ & & $65.9 \%$ \\
\hline
\end{tabular}

Notes: This table reports the results from regressing Discretionary Accruals and Accrual Quality on our IRS monitoring proxy and control variables. Discretionary Accruals is the absolute value of the residuals from industry/year regressions of accruals on the difference between the change in sales and the change in receivables, and total property plant and equipment (Jones 1991; Dechow et al. 1995). Accruals Quality is the Dechow and Dichev (2002) measure of accruals quality with the modification suggested by McNichols (2002) and equals the average absolute value of the past two year's residuals (multiplied by -100) from industry/year regressions of accruals on past, current, and future cash from operations, change in sales and change in property, plant and equipment. Size/Time Audit Probability is the number of returns whose audit was completed in IRS fiscal year $t$ in IRS asset size $s$ divided by the number of returns that were filed in IRS calendar year $t-1$ in IRS asset size $s$. The IRS monitoring proxy is adjusted for Coordinated Industry Case firms, so that the audit probability for the 1000 largest firms (by assets) in each year is set equal to 1. See Table 2 and Appendix B for details on how the other variables are defined. $* * *, * *$, and $*$ denote statistical significance at the one (two) tailed $1 \%, 5 \%$, and $10 \%$ levels when we (do not) have a directional prediction. 
TABLE 4

Regression of Financial Reporting Quality on alternative measures of IRS monitoring

\begin{tabular}{|c|c|c|c|c|c|c|}
\hline \multirow{2}{*}{$\begin{array}{l}\text { Dependent Variable: } \\
\text { Independent Variables }\end{array}$} & \multicolumn{4}{|c|}{ Discretionary Accruals } & \multicolumn{2}{|c|}{ Accrual Quality } \\
\hline & $\begin{array}{l}\text { Predicted } \\
\quad \text { Sign }\end{array}$ & $\begin{array}{l}\text { Coef. } \\
\text { (t-stat) }\end{array}$ & $\begin{array}{l}\text { Coef. } \\
\text { (t-stat) }\end{array}$ & $\begin{array}{l}\text { Predicted } \\
\text { Sign }\end{array}$ & $\begin{array}{l}\text { Coef. } \\
\text { (t-stat) }\end{array}$ & $\begin{array}{l}\text { Coef. } \\
\text { (t-stat) }\end{array}$ \\
\hline $\begin{array}{l}\text { District/Size/Time Audit } \\
\text { Probability }\end{array}$ & - & $-0.021 * * *$ & & + & $0.742 * * *$ & \\
\hline District/Time Audit Probability & - & $(-2.66)$ & $\begin{array}{c}-0.015 * * * \\
(-2.58)\end{array}$ & + & $(2.61)$ & $\begin{array}{l}0.226 \\
(1.16)\end{array}$ \\
\hline Ln MVE & & $\begin{array}{c}0.005 * * \\
(2.30)\end{array}$ & $\begin{array}{c}0.005 * * \\
(2.17)\end{array}$ & & $\begin{array}{c}0.219 * * \\
(2.46)\end{array}$ & $\begin{array}{l}0.243 * * * \\
\quad(2.74)\end{array}$ \\
\hline Proximity $\times$ SEC Budget & & $\begin{array}{l}0.000 \\
(0.03)\end{array}$ & $\begin{array}{l}-0.000 \\
(-0.01)\end{array}$ & & $\begin{array}{l}0.000 \\
(0.39)\end{array}$ & $\begin{array}{l}0.000 \\
(0.45)\end{array}$ \\
\hline SD Cash Flows & & $\begin{array}{l}-0.025 \\
(-0.80)\end{array}$ & $\begin{array}{l}-0.023 \\
(-0.77)\end{array}$ & & $\begin{array}{c}-8.643 * * * \\
(-7.96)\end{array}$ & $\begin{array}{c}-8.666 * * * \\
(-7.98)\end{array}$ \\
\hline Market to Book & & $\begin{array}{l}0.006 * * * \\
(3.80)\end{array}$ & $\begin{array}{l}0.006^{* * * *} \\
(3.88)\end{array}$ & & $\begin{array}{c}-0.141 * * * \\
(-2.96)\end{array}$ & $\begin{array}{c}-0.148 * * * \\
(-3.12)\end{array}$ \\
\hline Return on Assets & & $\begin{array}{c}-0.106 * * * \\
(-9.24)\end{array}$ & $\begin{array}{c}-0.106 * * * \\
(-9.23)\end{array}$ & & $\begin{array}{l}2.011 * * * \\
(5.60)\end{array}$ & $\begin{array}{l}2.002 * * * \\
(5.57)\end{array}$ \\
\hline Leverage & & $\begin{array}{l}0.040 * * * \\
(4.31)\end{array}$ & $\begin{array}{l}0.040 * * * \\
(4.28)\end{array}$ & & $\begin{array}{l}-0.264 \\
(-0.98)\end{array}$ & $\begin{array}{l}-0.222 \\
(-0.83)\end{array}$ \\
\hline SD Sales & & $\begin{array}{l}0.012 \\
(1.58)\end{array}$ & $\begin{array}{l}0.012 \\
(1.60)\end{array}$ & & $\begin{array}{c}-1.163 * * * \\
(-3.90)\end{array}$ & $\begin{array}{c}-1.169 * * * \\
(-3.92)\end{array}$ \\
\hline Operating Cycle & & $\begin{array}{c}-0.014 * * \\
(-2.46)\end{array}$ & $\begin{array}{c}-0.014^{* *} \\
(-2.46)\end{array}$ & & $\begin{array}{l}-0.009 \\
(-0.05)\end{array}$ & $\begin{array}{l}-0.006 \\
(-0.03)\end{array}$ \\
\hline Capital Intensity & & $\begin{array}{c}0.233 * * * \\
(15.99)\end{array}$ & $\begin{array}{c}0.233 * * * \\
(15.99)\end{array}$ & & $\begin{array}{c}-1.329 * * * \\
(-3.46)\end{array}$ & $\begin{array}{c}-1.343 * * * \\
(-3.50)\end{array}$ \\
\hline Intangible Intensity & & $\begin{array}{l}0.006 \\
(0.66)\end{array}$ & $\begin{array}{l}0.006 \\
(0.66)\end{array}$ & & $\begin{array}{c}0.833 * * * \\
(4.01)\end{array}$ & $\begin{array}{c}0.833 * * * \\
\quad(4.01)\end{array}$ \\
\hline Presence of Intangibles & & $\begin{array}{l}0.007 \\
(1.41)\end{array}$ & $\begin{array}{l}0.007 \\
(1.42)\end{array}$ & & $\begin{array}{l}0.067 \\
(0.34)\end{array}$ & $\begin{array}{c}0.063 \\
(0.31)\end{array}$ \\
\hline Negative Earnings & & $\begin{array}{c}0.026^{*} \\
(1.93)\end{array}$ & $\begin{array}{c}0.026^{* *} \\
(1.96)\end{array}$ & & $\begin{array}{c}-3.406^{* * *} \\
(-6.32)\end{array}$ & $\begin{array}{c}-3.426 * * * \\
(-6.35)\end{array}$ \\
\hline Year Fixed Effects & & Yes & Yes & & Yes & Yes \\
\hline Firm fixed Effects & & Yes & Yes & & Yes & Yes \\
\hline Firm Clustering & & Yes & Yes & & Yes & Yes \\
\hline Observations & & 38,653 & 38,653 & & 28,373 & 28,373 \\
\hline R-squared & & $54.1 \%$ & $54.1 \%$ & & $68.3 \%$ & $68.3 \%$ \\
\hline
\end{tabular}

Notes: This table reports the results from regressing Discretionary Accruals and Accrual Quality on the district based measures of IRS audit probability (District/Size/Time Audit Probability and District/Time Audit Probability) and control variables. District/Size/Time Audit Probability is the number of returns whose audit was completed in IRS fiscal year $t$ in IRS asset size $s$ in IRS district $d$ divided by the number of returns that were filed in IRS calendar year $t-1$ in IRS asset size $s$ in IRS district $d$. District/Time Audit Probability is the number of returns whose audit was completed in IRS fiscal year $t$ in IRS district $d$ divided by the number of returns that were filed in IRS calendar year $t$ 1 in IRS district $d$. Both IRS monitoring proxies are adjusted for Coordinated Industry Case firms, so that the audit probability for the 1000 largest firms (by assets) in each year is set equal to 1. See Table 2 and Appendix B reports the details of variable construction. $* * *, * *$, and $*$ denote statistical significance at the one (two) tailed 1\%, 5\%, and 10\% levels when we (do not) have a directional prediction. 


\section{TABLE 5}

Regression of our measures of Financial Reporting Quality on Audit Probability with Audit Probability interacted with proxies for the availability of alternative monitoring mechanisms

\begin{tabular}{|c|c|c|c|c|c|c|}
\hline \multirow{2}{*}{$\begin{array}{l}\text { Dependent Variable: } \\
\text { Independent Variables }\end{array}$} & \multicolumn{4}{|c|}{ Discretionary Accruals } & \multicolumn{2}{|c|}{ Accrual Quality } \\
\hline & $\begin{array}{l}\text { Predicted } \\
\text { Sign }\end{array}$ & $\begin{array}{l}\text { Coefficient } \\
\text { (t-statistic) }\end{array}$ & $\begin{array}{l}\text { Coefficient } \\
\text { (t-statistic) }\end{array}$ & $\begin{array}{l}\text { Predicted } \\
\text { Sign }\end{array}$ & $\begin{array}{l}\text { Coefficient } \\
\text { (t-statistic) }\end{array}$ & $\begin{array}{l}\text { Coefficient } \\
\text { (t-statistic) }\end{array}$ \\
\hline Audit Probability & - & $\begin{array}{c}-0.049 * * * \\
(-5.69)\end{array}$ & $\begin{array}{c}-0.034 * * * \\
(-5.16)\end{array}$ & + & $\begin{array}{c}1.474 * * * \\
(4.45)\end{array}$ & $\begin{array}{c}0.843 * * * \\
(3.27)\end{array}$ \\
\hline Institutional Investors & - & $\begin{array}{c}-0.069 * * * \\
(-7.97)\end{array}$ & & + & $\begin{array}{c}1.245^{* * *} * \\
(3.42)\end{array}$ & \\
\hline Institutional Investors x Audit Probability & + & $\begin{array}{c}0.052 * * * \\
(5.01)\end{array}$ & & - & $\begin{array}{c}-1.620^{* * *} \\
(-3.67)\end{array}$ & \\
\hline Dedicated Investors & - & & $\begin{array}{c}-0.104 * * * \\
(-4.28)\end{array}$ & + & & $\begin{array}{c}1.980^{* *} \\
(1.76)\end{array}$ \\
\hline Dedicated Investors x Audit Probability & + & & $\begin{array}{c}0.093^{* * *} \\
(2.94)\end{array}$ & - & & $\begin{array}{l}-1.985^{*} \\
(-1.41)\end{array}$ \\
\hline Control Variables & & Yes & Yes & & Yes & Yes \\
\hline Year Fixed Effects & & Yes & Yes & & Yes & Yes \\
\hline Firm Fixed Effects & & Yes & Yes & & Yes & Yes \\
\hline Firm Clustering & & Yes & Yes & & Yes & Yes \\
\hline Observations & & 64,982 & 64,982 & & 46,338 & 46,338 \\
\hline R-squared & & $51.5 \%$ & $51.5 \%$ & & $65.9 \%$ & $65.9 \%$ \\
\hline
\end{tabular}

Notes: This table reports the results from regressing our financial reporting quality measures on our IRS monitoring measure conditioning on level of outside monitoring. We measure outside monitoring using the following variables: 1) Institutional Investors is the percentage of the firm's equity held by institutional investors in year $\mathrm{t}$, and 2) Dedicated Investors is the percentage of the firm's equity held by dedicated institutional investors (as defined in Bushee 1998) in year t. See Appendix B for details on how the other variables are defined. ***,**, and * denote statistical significance at the one (two) tailed $1 \%, 5 \%$, and $10 \%$ levels when we (do not) have a directional prediction. 


\section{TABLE 6}

Regressions of Stock Returns on Changes in Earnings around the election of Vladimir Putin

\begin{tabular}{|c|c|c|c|}
\hline \multirow{2}{*}{$\begin{array}{l}\text { Dependent Variable: } \\
\text { Independent Variables }\end{array}$} & \multirow[b]{2}{*}{$\begin{array}{l}\text { Predicted } \\
\text { Sign }\end{array}$} & \multicolumn{2}{|c|}{ Annual Stock Returns } \\
\hline & & $\begin{array}{l}\text { Coefficient } \\
\text { (t-statistic) }\end{array}$ & $\begin{array}{l}\text { Coefficient } \\
\text { (t-statistic) }\end{array}$ \\
\hline Change in Earnings & + & $\begin{array}{c}0.004 * * * \\
(2.60)\end{array}$ & $\begin{array}{c}0.008 * * * \\
(3.60)\end{array}$ \\
\hline Post Putin Indicator & & $\begin{array}{c}-1.436 * * * \\
(-6.77)\end{array}$ & $\begin{array}{l}-0.651 \\
(-1.30)\end{array}$ \\
\hline Change in Earnings $\times$ Post Putin Indicator & + & $\begin{array}{c}0.073^{* * *} \\
(16.37)\end{array}$ & $\begin{array}{c}0.069^{* * *} \\
(11.20)\end{array}$ \\
\hline Non-ADR Indicator & & & $\begin{array}{l}-0.166 \\
(-0.27)\end{array}$ \\
\hline Change in Earnings $\times$ Non-ADR Indicator & + & & $\begin{array}{c}0.215^{* * *} \\
(17.79)\end{array}$ \\
\hline Post Putin Indicator $\times$ Non-ADR Indicator & & & $\begin{array}{l}0.111 \\
(0.15)\end{array}$ \\
\hline Change in Earnings $\times$ Post Putin Indicator $\times$ Non-ADR Indicator & + & & $\begin{array}{c}0.332 * * * \\
(5.52)\end{array}$ \\
\hline Constant & & $\begin{array}{c}1.794 * * * \\
(10.02)\end{array}$ & $\begin{array}{c}1.028 * * \\
(2.42)\end{array}$ \\
\hline Observations & & 60 & 60 \\
\hline R-squared & & $18.1 \%$ & $51.9 \%$ \\
\hline
\end{tabular}

Notes: This table examines whether earnings informativeness improved following the increase in tax enforcement implemented by Vladimir Putin upon his election, and whether the improvement in earnings informativeness is greater for firms without American Depository Receipts (ADRs). The dependent variable in the above regressions is Annual Stock Returns which is calculated by compounding daily returns (adjusted for stock splits and dividends) from May to April for the primary equity of the firm (Compustat Global variable: IID="01W"). The independent variables include the following variables. Change in Earnings is calculated as the change in earnings before extraordinary items scaled by the market value of equity at the beginning of the year [i.e., $\left(\mathrm{IB}_{\mathrm{t}}-\mathrm{IB}_{\mathrm{t}-1}\right) /\left(\mathrm{PRCCD}_{\mathrm{t}-}\right.$ $\left.\left.{ }_{1}{ }^{*} \mathrm{CSHOC}_{\mathrm{t}-1}\right)\right]$. Post Putin Indicator is an indicator variable which takes on the value of one (zero) for firm-year observations after (before) 2000 - the years following the election of Vladimir Putin. And Non-ADR Indicator is an indicator variable which takes on the value of one (zero) if the firm's equity is not cross-listed in a U.S. stock exchange as an ADR. We obtain data for the above test from Compustat Global. Our sample consists of the entire population of firms covered by Compustat Global that are incorporated in Russia (Compustat Global variable: FIC="RUS") that have fiscal years ending on $31^{\text {st }}$ December for the period 1998-2002 (excluding the year 2000 because it is the year in which Vladimir Putin was elected). We eliminate all firm-year observations that do not have a stock price for at least 52 trading days in a year. The above criteria leave 60 firm-year observations in our sample. We estimate our regressions using the Least Absolute Deviation estimator. ***, **, and * denote statistical significance at the one (two) tailed 1\%,5\%, and 10\% levels when we (do not) have a directional prediction. 
TABLE 7

Time series regressions of annual aggregate Financial Reporting Quality on annual IRS expenditures and annual SEC expenditures from 1965 to 2008

\begin{tabular}{|c|c|c|c|c|c|c|}
\hline \multirow{2}{*}{$\begin{array}{l}\text { Dependent Variable: } \\
\text { Independent Variables }\end{array}$} & \multicolumn{4}{|c|}{$\begin{array}{l}\text { Aggregate Accrual } \\
\text { Quality }\end{array}$} & \multicolumn{2}{|c|}{$\begin{array}{c}\text { Aggregate Discretionary } \\
\text { Accruals }\end{array}$} \\
\hline & $\begin{array}{l}\text { Predicted } \\
\text { Sign }\end{array}$ & $\begin{array}{l}\text { Coefficient } \\
\text { (t-statistic) }\end{array}$ & $\begin{array}{l}\text { Coefficient } \\
\text { (t-statistic) }\end{array}$ & $\begin{array}{l}\text { Predicted } \\
\text { Sign }\end{array}$ & $\begin{array}{l}\text { Coefficient } \\
\text { (t-statistic) }\end{array}$ & $\begin{array}{l}\text { Coefficient } \\
\text { (t-statistic) }\end{array}$ \\
\hline IRS Expenditure / Total US Outlay & + & $\begin{array}{l}10.363^{* * *} \\
(2.43)\end{array}$ & $\begin{array}{l}5.891 * \\
(1.64)\end{array}$ & - & $\begin{array}{c}-12.880 * * * \\
(-3.00)\end{array}$ & $\begin{array}{l}-8.920 * * \\
(-2.19)\end{array}$ \\
\hline SEC Expenditure / Total US Outlay & + & & $\begin{array}{c}56.394 * * * \\
(3.98)\end{array}$ & - & & $\begin{array}{c}-49.930 * * * \\
(-3.46)\end{array}$ \\
\hline Constant & & $\begin{array}{c}-0.090 * * * \\
(-8.90)\end{array}$ & $\begin{array}{r}-0.081 * * * \\
(-10.68)\end{array}$ & & $\begin{array}{r}0.125 * * * \\
(12.81)\end{array}$ & $\begin{array}{r}0.118 * * * \\
(13.48)\end{array}$ \\
\hline Newey-West Standard Errors with o & e lag & Yes & Yes & & Yes & Yes \\
\hline Observations & & 44 & 44 & & 44 & 44 \\
\hline R-Squared & & $18.3 \%$ & $47.6 \%$ & & $24.6 \%$ & $44.6 \%$ \\
\hline
\end{tabular}

Notes: This table reports the results from time-series regressions of Aggregate Accrual Quality and Aggregate Discretionary Accruals on IRS and SEC enforcement measured using their respective annual expenditures on enforcement. Aggregate Accruals Quality is measured as -1 times the average absolute residuals each year from modified Dechow and Dichev (2002) regressions estimated at the Fama-French industry level using all firm-year observations for the years 1965-2008. Aggregate Discretionary Accruals is measured as the average absolute residuals each year from modified Jones (1991) model regressions estimated at the Fama-French industry level using all firm-year observations for the years 1965-2008. IRS Expenditure / Total US Outlay is the gross total expense of the IRS's tax enforcement activities scaled by total U.S. government outlays (http://www.gpoaccess.gov /usbudget/fy10/db.html). SEC Expenditure / Total U.S. Outlay is the net total expense of the SEC's tax law enforcement activities scaled by total U.S. government outlays (http://www.gpoaccess.gov/usbudget/fy10/db.html). $* * *, * *$, and $*$ denote statistical significance at the one (two) tailed 1\%, 5\%, and 10\% levels when we (do not) have a directional prediction. 